\title{
Analysis of Hydrogeochemical Characteristics of Tunnel Groundwater Based on Multivariate Statistical Technology
}

\author{
Chen Peng, ${ }^{1}$ Yuanming Liu ${ }^{10},{ }^{1}$ Huiyu Chen, ${ }^{1}$ Qiaowei Yuan, ${ }^{1}$ Qingzhi Chen $\left(\mathbb{D},{ }^{1}\right.$ \\ Shilong Mei, ${ }^{2}$ and Zhonghu Wu (iD) ${ }^{1}$ \\ ${ }^{1}$ School of Civil Engineering, Guizhou University, Guiyang 550000, China \\ ${ }^{2}$ School of Architecture and Urban Planning, Guizhou University, Guiyang 550000, China \\ Correspondence should be addressed to Yuanming Liu; liuym_2021@163.com
}

Received 23 September 2021; Accepted 13 November 2021; Published 6 December 2021

Academic Editor: Haojie Lian

Copyright (c) 2021 Chen Peng et al. This is an open access article distributed under the Creative Commons Attribution License, which permits unrestricted use, distribution, and reproduction in any medium, provided the original work is properly cited.

\begin{abstract}
Following tunnel excavation, which is influenced by hydraulic fracturing and geological structure, a series of hydrochemical reactions occur in the karst aquifer, which has a significant impact on groundwater hydrology and the earth process. Based on five sets of 38 samples collected in the Tongzi Tunnel in 2020 and 2021, the main geochemical processes and water quality conditions of the karst aquifer system during tunnel construction were revealed by multivariate statistical analysis and graphical methods. The results showed that water-rock action is the main mechanism controlling groundwater chemistry in the study area $\mathrm{HCO}_{3}{ }^{-}, \mathrm{Ca}^{2+}$, and $\mathrm{Mg}^{2+}$ are associated with the widely distributed carbonate rocks in the study area. $\mathrm{SO}_{4}{ }^{2-}$ is derived from gypsum and sulfate rocks and special strata, which are another important source of $\mathrm{Ca}^{2+}$. Sodium-containing silicates and reverse cation exchange as the causal mechanisms of $\mathrm{Na}^{+}$whereas $\mathrm{F}^{-}$is derived from fluorite. According to the mineral saturation index calculations, the dissolution and precipitation of minerals such as alum, gypsum, calcite, dolomite, and salt rock have an important influence on the main chemical components in water. The 38 samples were subjected to cluster analysis, and the results could be classified into seven categories. The representative clusters 1,3 , and 5 were selected for principal component analysis. Clusters 1 and 5 of groundwater represent weathering, dissolution, and ion exchange of carbonate and sulfate rocks and are closely related to the lithologic limestone, limestone intercalated with carbonaceous mudstone, carbonaceous mudstone, and coal-measure strata in the aquifer. Cluster 3 is dominated by upper surface river water and characterizes the geochemistry in natural water bodies dominated by the dissolution of carbonate, sulfate, and salt rocks. Finally, groundwater quality is mostly found in Class $\mathrm{IV}$, with $\mathrm{NO}_{3}{ }^{-}$and $\mathrm{F}^{-}$being the main contaminants in the water.
\end{abstract}

\section{Introduction}

In the karst areas of southwest China, tunneling is the main way to improve transportation due to the special topographical features. When tunnels pass through geological units of different lithological formations, there will inevitably be a significant impact on the karst aquifer system, especially in deeply buried tunnels with high ground stresses. Tunnel excavation usually creates a hydraulic fracturing effect, in which cracks in the surrounding rock sprout and expand under the action of hydraulic splitting, creating new drainage channels and causing significant changes in groundwater [1]. Hydraulic fracturing has become a central mechanism for water damage in some high water pressure tunnels. At the same time, hydraulic fractures and water pressure also provide sites and conditions for aquifer water-rock action, leading to a series of hydrochemical reactions that affect the groundwater chemical field.

Relevant studies have shown that the construction of underground works has a significant impact on the hydrogeochemical processes and groundwater quality of aquifers. Chae et al. analyzed 72 sets of tunnel seepage samples collected from 43 underground stations in Korea and found that hydrogeological interactions caused by underground construction altered water chemistry and led to the deterioration of groundwater quality [2]. Based on a study of groundwater flow conditions around the Chienberg Tunnel, Butscher et al. found that groundwater from different 
aquifers mixed after tunnel excavation and that coupled hydraulic-mechanical and geochemical effects altered the pore water chemistry and caused swelling of the gypsum salt rock [3]. Piña et al. modeled the path of surface water into the tunnels using hydrochemical analyses and isotopic techniques and found that the depth of burial of the tunnels affects the intensity and timing of water-rock action and that carbon dioxide and oxygen in the air react with the exposed minerals [4]. This type of alteration of the dissolution state of minerals due to the renewal of aquifers by tunnel drainage, resulting in hydrogeochemical imbalances, is common in all types of rock formations [5]. The impact on water quality and water chemistry is even more pronounced if the tunnel passes directly through underground karst aquifers and fracture zones [6].

Along with the natural chemical reactions caused by the hydraulic fracturing effect of tunnels and groundwater exchange, explosive residues used in tunnel construction by blasting can also directly affect groundwater quality, the most significant effect being a surge in $\mathrm{NH}_{4}{ }^{+}$and $\mathrm{NO}_{3}{ }^{-}$in groundwater [7]. Contaminated groundwater can also damage the surrounding rock and tunnel structure, Ghobadi et al. investigated the groundwater chemistry of Iranian metro line 2, finding that the gypsum, hard gypsum, and coal contained in the strata after the construction of the tunnels had a significant impact on groundwater quality, and the sulfates and chlorides produced by the reaction make the groundwater corrosive to the tunnel linings [8]. Howladar and Rahman conducted a study on the quality of tunnel drainage, and the results showed that water quality has an impact on biology and drinking. Natural processes and human activities are the main control factors for water pollution sources [9]. It can be seen that the influence of tunnel water-rock action on groundwater chemistry and water quality cannot be ignored. It is related to multiple factors such as stratum lithology, groundwater storage conditions, hydraulic strength, and tunnel construction.

Multivariate statistical analysis has been successfully applied to hydrogeochemical studies in many fields. Megherfi et al. applied multivariate statistical analysis to group the groundwater chemistry in the study area and revealed the main controlling processes of the hydrochemical characteristics [10]. Engle and Rowan used multivariate analysis to study the geochemical data of injected water and produced water during hydraulic fracturing of shale gas wells [11]. Pan et al. evaluated the irrigating properties of groundwater near landfills through multiple statistical methods [12]. Kumar et al. introduced principal component analysis and cluster analysis in water quality evaluation, and the results showed that multivariate statistical methods can reasonably explain large data sets and reduce the cost of water quality monitoring [13]. Prusty and Farooq used multivariate statistical methods to reveal the mechanism of seawater's influence on groundwater and surface water, providing a basis for water resource management [14].

The karst area has a complex geological structure, widespread faults and caves, and rich mineral resources, and the karst groundwater system is extremely sensitive to tunnel construction. Although some scholars have studied the hydrogeochemical processes induced by mining activities in the karst areas of Southwest China $[15,16]$, however, there are no reports on groundwater chemistry in the karst tunnel fracture zone; the existing research on groundwater related to tunnel mainly focuses on the influence of groundwater level decline and water pressure on the safety of lining structure, lack of understanding of groundwater and surrounding rock matrix water-rock interaction. As a result, it is critical to conduct groundwater chemical processes and water quality research for karst tunnels. The Tongzi Tunnel, an extralong highway tunnel under construction in Guizhou Province, serves as the research material in this study. Through indoor experiments, combined with hydrochemical methods and multivariate statistical methods, the Tongzi Tunnel groundwater chemical characteristics and water quality are evaluated, aiming to understand the water-rock interaction and hydrochemical evolution mechanism caused by tunnel construction.

\section{Overview of the Study Area}

2.1. Location. The Tongzi Tunnel is $10.5 \mathrm{~km}$ long and is located at the deflection extension of Dalou Mountain. It is an important part of the expansion project of the Chongqing-Zunyi section of the Lanzhou-Haikou Expressway. Geographically, the tunnel is located in two towns in Tongzi County, Guizhou Province. With the watershed in the middle of the tunnel as the boundary, the Chongqing side is under the jurisdiction of Dahe Township, while the Zunyi side is under the jurisdiction of Mazong Township. Construction of the tunnel started in June 2018 and is expected to be completed and commence traffic by the end of 2022. The location of the study area is shown in Figure 1(a).

2.2. Hydrology. The surface basins of the tunnel belong to the Qijiang River system, Chishui River system, and Wujiang River system in the Yangtze River Basin. There is no perennial surface runoff around the tunnel. The rivers are mainly supplied by precipitation, or shallow short streams are formed due to springs exposed in gullies. With the surface watershed as the boundary, the surface runoff of the Chongqing section flows into the Songkan River, and the surface runoff of the Zunyi section flows into the Tongzi River. Figure 1(b) shows the monthly average rainfall in Tongzi County from 1990 to 2011. May-August is the rainy season, the rainfall peaks in June, and the rainfall gradually decreases from August with a short peak in October. Groundwater flow and water level lag for several or tens of days after rainfall and the overall change are coordinated with precipitation.

2.3. Stratum Lithology and Bad Geology. The Tongzi Tunnel has a large buried depth, complex geological structure, and diverse lithology. The overlying Quaternary soil layer is scattered. The geological section is shown in Figure 1(c). The maximum horizontal principal stress value of the cave body measured by the hydraulic fracturing test in the 


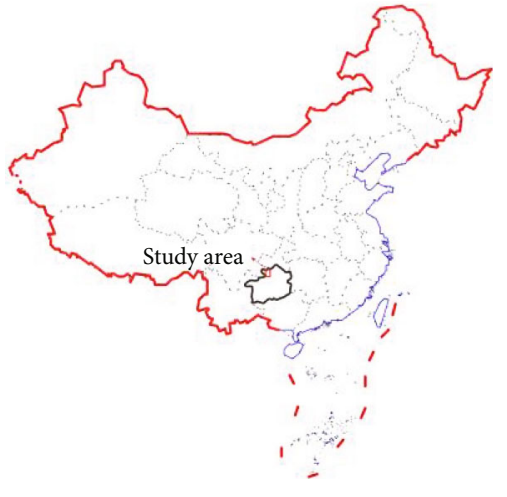

(a)

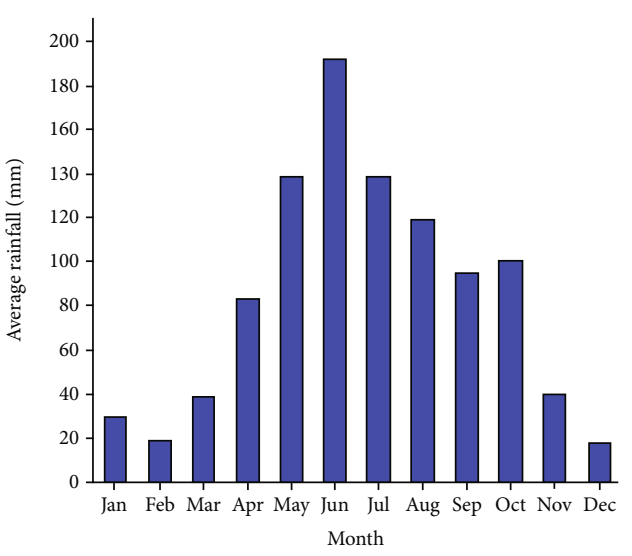

(b)

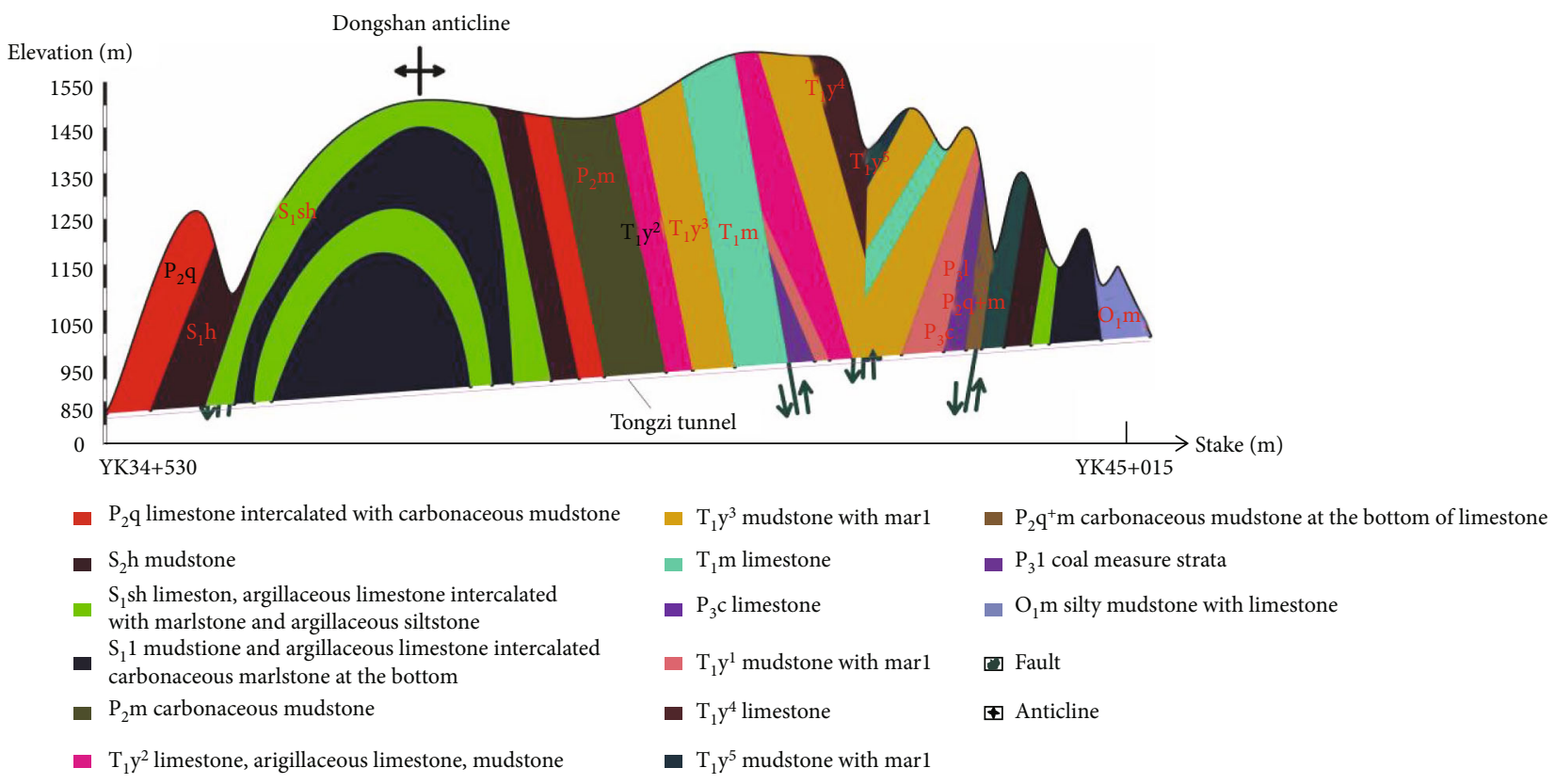

(c)

FIGURE 1: (a) Location of the study area. (b) Monthly average rainfall in the study area from 1995 to 2011. (c) Geological profile of Tongzi Tunnel.

deeply buried section is $9.43 \sim 21.84 \mathrm{MPa}$; at the same time, it also traverses the Kaijianpu fault, Linghujiayakou fault, water outlet fault, and Yemaodong fault. The exit section of the tunnel passes through the mine boundary of Tuanyuan Coal Mine in Mazong Township, and the old kiln water may collude through the preset roadway. During the geological prospecting stage, a water quality test was performed on the S1 spring point water in the $T_{1} m$ formation and the $\mathrm{P}_{3} \mathrm{l}$ coal measure formation water in the Tuanyuan coal mine coal tunnel. The test results show that the water quality of the groundwater within $\mathrm{T}_{1} \mathrm{~m}$ and the stream water at the exit of the tunnel is made up of calcium carbonate. Surface water and groundwater are slightly corrosive to reinforced concrete structures. The underground water of Tuanyuan Coal Mine $\left(\mathrm{P}_{3} \mathrm{l}\right)$ constitutes potassium sodium sulfate, whereby groundwater in coal-bearing strata is weakly corrosive to reinforced concrete structures.

\section{Materials and Methods}

3.1. Experimental Sampling. The groundwater outflow point of the tunnel is mainly located in the fault fracture zone. According to research purpose, the sampling was carried out mainly on the Yemaodong fault, the water outlet fault, and the Linghujiayakou fault. 34 groundwater samples were collected in July 2020 (group I), October 2020 (group II), December 2020 (group III), March 2021 (group IV), and April 2021 (group V). They are secondary lining water outlets or leakage without lining after excavation and are not mixed with other water samples. Four surface glasses of water were collected in July 2020 (group S-I), October 2020 (group S-II), and March 2020 (group S-IV). The river is located on the surface of the upper part of the tunnel, and its flow is affected by rainfall, but there is no cut-off in the dry season which allows water to flow uniformly. Figure 2 depicts the distribution of sampling point locations. 


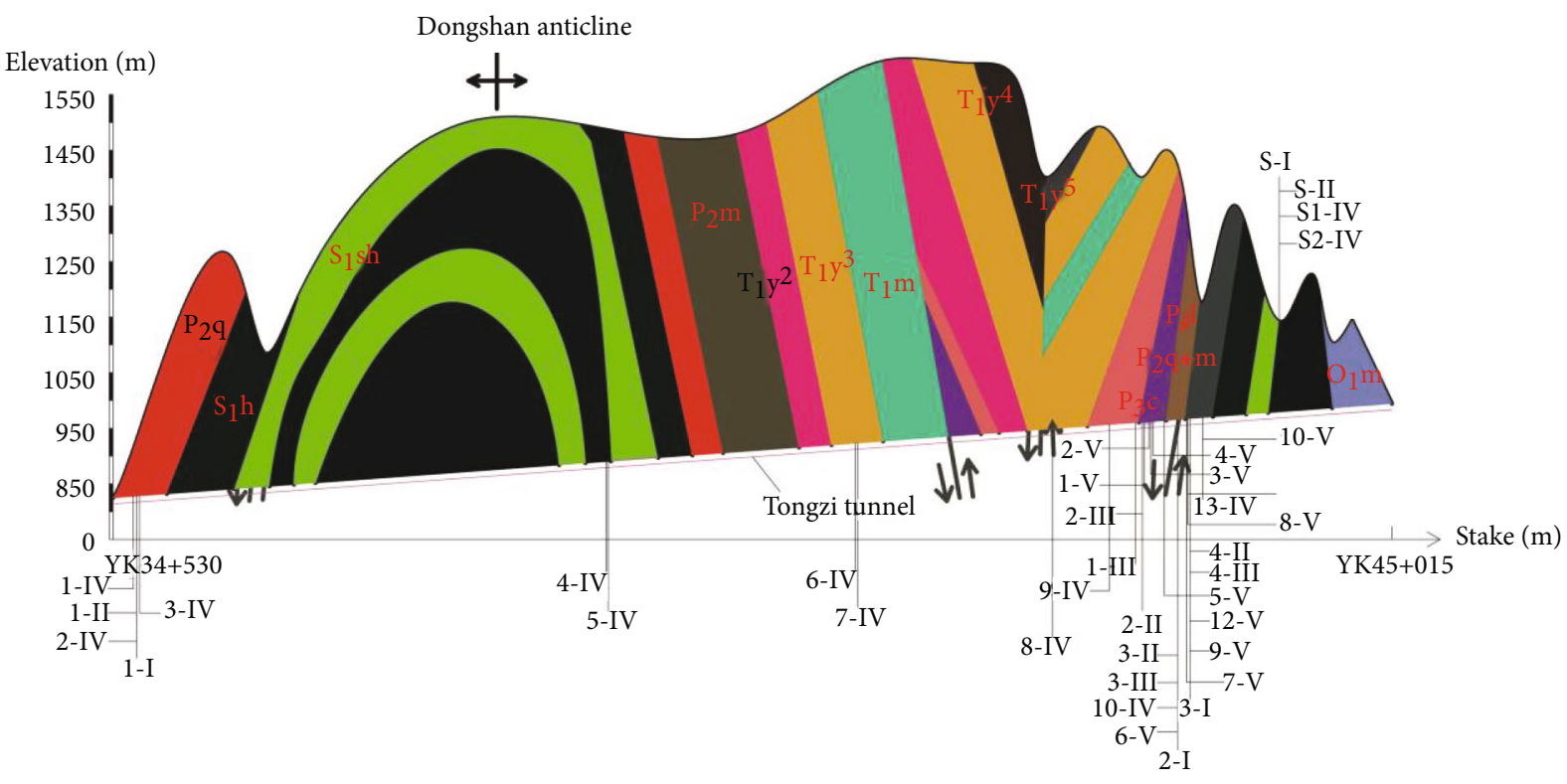

FIGURE 2: Location and number of sampling points.

TABLE 1: Conventional indexes and limits of groundwater quality $(\mathrm{mg} / \mathrm{L})$.

\begin{tabular}{lcccccccccccc}
\hline Class & $\mathrm{pH}$ & $\mathrm{TDS}$ & $\mathrm{SO}_{4}^{2-}$ & $\mathrm{Cl}^{-}$ & $\mathrm{Fe}$ & $\mathrm{Al}$ & $\mathrm{NH}_{4}^{+}$ & $\mathrm{Na}^{+}$ & $\mathrm{NO}_{3}^{-}$ & $\mathrm{F}^{-}$ & $\mathrm{As}^{-}$ \\
\hline $\mathrm{I}$ & 8.5 & 300 & 50 & 50 & 0.1 & 0.01 & 0.02 & 100 & 2 & 1 \\
II & 8.5 & 500 & 150 & 150 & 0.2 & 0.05 & 0.1 & 150 & 5 & 1 & 0.001 \\
III & 8.5 & 1000 & 250 & 250 & 0.3 & 0.2 & 0.5 & 200 & 20 & 1 \\
IV & 9 & 2000 & 350 & 350 & 2 & 0.5 & 1.5 & 400 & 30 & 2 & 0.01 \\
V & 9 & 2000 & 350 & 350 & 2 & 0.5 & 1.5 & 400 & 30 & 2 & 0.05 \\
\hline
\end{tabular}

3.2. Experimental Method. The sampling bottle was cleaned with deionized water before sampling and rinsed with sample water more than three times during sampling. After sampling, the sample water was fitted with $0.22 \mu \mathrm{m}$ and $0.45 \mu \mathrm{m}$ membranes and put into a $150 \mathrm{~mL}$ polyethylene bottle. $\mathrm{pH}$, TDS, and EC are measured by a portable $\mathrm{pH}$ meter and composite electrode. The concentration of $\mathrm{HCO}_{3}{ }^{-}$is determined by titration, cationic $\left(\mathrm{K}^{+}, \mathrm{Ca}^{2+}, \mathrm{Na}^{+}\right.$, and $\left.\mathrm{Mg}^{2+}\right)$ samples are acidified with nitric acid dropwise, and the concentration is determined by flame atomic absorption spectrophotometry with TAS-990 instrument whereas anions $\left(\mathrm{SO}_{4}{ }^{2-}, \mathrm{NO}_{3}{ }^{-}, \mathrm{Cl}^{-}\right.$, and $\left.\mathrm{F}^{-}\right)$are analyzed by ion chromatography with ICS-1100 instrument. $\mathrm{NH}_{4}^{+}$was determined by $\mathrm{Na}$ 's reagent spectrophotometry. The metal elements are determined by inductively coupled plasma mass spectrometry by ICP-MS instruments. The experiment process strictly follows the relevant specifications.

\subsection{Analysis Method}

3.3.1. Hydrochemical Methods. Common water chemistry analysis methods include Piper's three-line diagram, Gibbs model, and ion scatter diagram. The Piper three-line diagram consists of two triangles representing the percentages of the main anions and cations in milligram equivalents. Two triangles are integrated into the middle diamond- shaped part to form a point for identifying the groundwater chemical phase [17]. The Gibbs model is divided into three regions by TDS and $\mathrm{Na}+/\left(\mathrm{Na}^{+}+\mathrm{Ca}^{2+}\right)$ and $\mathrm{Cl}^{-} /\left(\mathrm{Cl}^{-}+\mathrm{HC}\right.$ $\left.\mathrm{O}_{3}{ }^{-}\right)$, revealing the chemical control factors of groundwater, namely, atmospheric precipitation, rock weathering, and evaporative crystallization [18]. The concentration relationship between the main ions can determine the source of solute and the chemical process of groundwater.

The chloride alkalinity index can be used to determine whether there is cation cross-adsorption in groundwater. As shown in formulas (1) and (2), if CAI 1 and CAI 2 are both positive, it indicates that $\mathrm{Na}^{+}$and $\mathrm{K}^{+}$in groundwater exchange with $\mathrm{Ca}^{2+}$ and $\mathrm{Mg}^{2+}$ in the surrounding rock, and if they are negative at the same time, the reverse direction exchange occurs [19].

$$
\begin{aligned}
& \mathrm{CAI} 1=\frac{\left[\mathrm{Cl}^{-}-\left(\mathrm{Na}^{+}+\mathrm{K}^{+}\right)\right]}{\mathrm{Cl}^{-}}, \\
& \mathrm{CAI} 2=\frac{\left[\mathrm{Cl}^{-}-\left(\mathrm{Na}^{+}+\mathrm{K}^{+}\right)\right]}{\mathrm{HCO}_{3}^{-}+\mathrm{SO}_{4}^{2-}+\mathrm{NO}_{3}^{-}+\mathrm{CO}_{3}^{2-}} .
\end{aligned}
$$

3.3.2. PHREEQC Simulation. PHREEQC simulation is an important method to identify water chemical reactions and physical processes. One of them is the calculation of the 
TABLE 2: Evaluation score of single index and comprehensive evaluation score.

\begin{tabular}{lccccc}
\hline Class & I & II & III & IV & V \\
\hline Evaluation score of single index $F_{i}$ & 0 & 1 & 3 & 6 & 10 \\
Comprehensive evaluation score $F$ & $<0.80$ & $0.80 \sim 2.50$ & $2.50 \sim 4.25$ & $4.25 \sim 7.20$ & $>7.20$ \\
\hline
\end{tabular}

TABLE 3: Statistics of hydrochemical parameters (mg/L).

\begin{tabular}{|c|c|c|c|c|c|c|c|c|c|c|c|c|c|c|c|}
\hline & $\mathrm{H}$ & $\mathrm{EC}$ & TDS & $\mathrm{HCO}_{3}{ }^{-}$ & $\mathrm{SO}_{4}{ }^{2-}$ & $\mathrm{Cl}^{-}$ & $\mathrm{NO}_{3}^{-}$ & $\mathrm{F}^{-}$ & $\mathrm{Ca}^{2+}$ & $\mathrm{Mg}^{2+}$ & $\mathrm{Na}^{+}$ & $\mathrm{K}^{+}$ & $\mathrm{NH}_{4}^{+}$ & $\mathrm{Fe}$ & $\mathrm{Al}$ \\
\hline $1-I$ & 8.12 & 354.00 & 176.00 & 68.27 & 5.16 & 2.55 & 27.80 & 0.31 & 29.68 & 31.80 & 14.50 & 4.10 & 0.12 & 0.35 & 0.05 \\
\hline $2-I$ & 12 & 260.00 & 129.00 & 53.05 & 26.34 & 1.32 & 3.48 & 0.33 & 19.54 & 60.68 & 12.74 & 15.50 & 0.13 & 0.21 & 0.09 \\
\hline $3-I$ & 06 & 633.00 & 315.00 & 112.11 & 203.09 & 1.32 & 6.58 & 0.27 & 55.16 & 142.60 & 8.36 & 5.02 & 0.97 & 0.62 & 0.04 \\
\hline 1-II & 33 & 268.00 & 134.00 & 92.09 & 25.76 & 3.15 & 41.25 & 0.24 & 43.00 & 6.14 & 19.19 & 2.28 & 0.00 & 0.20 & 0.09 \\
\hline 2-II & 8.31 & 238.00 & 120.00 & 108.08 & 31.89 & 0.83 & 2.85 & 0.34 & 56.20 & 3.64 & 8.37 & 0.90 & 0.00 & 0.21 & 0.03 \\
\hline 3-II & 8.34 & 367.00 & 183.00 & 82.08 & 135.40 & 1.26 & 0.88 & 0.25 & 50.62 & 14.64 & 16.03 & 6.74 & 0.11 & 0.26 & 0.04 \\
\hline 4-II & 31 & 404.00 & 203.00 & 134.13 & 124.12 & 1.29 & 0.89 & 0.28 & 84.36 & 12.96 & 10.44 & 2.07 & 0.03 & 0.41 & 0.02 \\
\hline 1-III & 56 & 252.00 & 126.00 & 190.69 & 30 & 1.01 & 3.41 & 0.53 & 3 & 2 & 14.66 & 0.82 & 0.37 & 0.54 & 0.03 \\
\hline 2-III & 57 & 315.00 & 157.00 & 20 & 68. & 0. & 1.76 & 0 & 3 & 4.04 & 1 & 1. & 0 . & 1 & 0.06 \\
\hline 3-III & 57 & 472.00 & 238 & 43 & 220 & 1.66 & 0 & 0 & J & 7.22 & 0 & 13 & 4 & 60 & 0.03 \\
\hline 4-III & 58 & 44 & 220 & 17 & 1 & 1 & 4 & 0 & J & 6.19 & 9 & 3.31 & 0 & 67 & 0.02 \\
\hline $1-I V$ & 57 & 305.00 & 1 & 04 & 5 & 4 & 4 & 2 & & & 3 & 9 & 0 & 16 & 0.06 \\
\hline 2-IV & 58 & 297.00 & 14 & 122.04 & 5 & 3.80 & 7 & 2.20 & 3 & 4.60 & 3 & 4 & 5 & 2 & 0.06 \\
\hline 3-IV & 58 & 293.00 & 145.00 & 122.04 & 5 & 3.91 & 38.67 & 2.17 & 3 & 4.5 & 3 & 5.17 & 0 & 0 & 0.07 \\
\hline 4-IV & 8.67 & 298.00 & 149.00 & 156.36 & 14.43 & 1.12 & 2.38 & 0.87 & 0 & 0 . & 89 & 3.75 & 0.07 & 0.00 & 0.27 \\
\hline 5-IV & 8.67 & 294.00 & 147.00 & 183.06 & 14.47 & 1.22 & 1.59 & 0.81 & 0.00 & 0.53 & 90.68 & 1.09 & 0.05 & 0.00 & 0.05 \\
\hline 6-IV & 8.57 & 315.00 & 158.00 & 194.50 & 62.26 & 1.43 & 0.27 & 1.49 & 31.13 & 7.11 & 48.43 & 2.03 & 0.08 & 0.29 & 0.02 \\
\hline 7-IV & 8.61 & 298.00 & 149.00 & 160.18 & 66.19 & 1.42 & 0.74 & 1.46 & 25.15 & 6.86 & 47.95 & 3.18 & 0.00 & 0.24 & 0.05 \\
\hline 8-IV & 8.65 & 170.00 & 84.00 & 106.79 & 24.09 & 0.36 & 0.11 & 0.33 & 0.23 & 0.02 & 52.22 & 0.94 & 0.00 & 0.00 & 0.04 \\
\hline 9-IV & 8.64 & 290.00 & 144.00 & 91.53 & 76.48 & 0.97 & 1.57 & 2.46 & 0.85 & 0.12 & 83.37 & 3.44 & 0.00 & 0.00 & 0.28 \\
\hline $10-\mathrm{IV}$ & 8.62 & 234.00 & 116.00 & 0.00 & 90.59 & 1.98 & 9.05 & 0.60 & 7.65 & 2.83 & 44.79 & 14.60 & 0.00 & 0.09 & 0.25 \\
\hline $11-I V$ & 8.56 & 476.00 & 240.00 & 221.20 & 162.81 & 1.85 & 4.65 & 0.20 & 75.34 & 6.49 & 16.47 & 3.63 & 0.00 & 1.08 & 0.01 \\
\hline $12-\mathrm{IV}$ & 8.59 & 433.00 & 215.00 & 198.32 & 141.64 & 1.92 & 6.62 & 0.24 & 62 & 5 & 17.00 & 3.49 & 0.00 & 0.87 & 0.01 \\
\hline $13-I V$ & 8.58 & 419.00 & 209.00 & 179.25 & 139.84 & 1.97 & 6.06 & 0.24 & 67 & 5. & 17.86 & 3.93 & 0.00 & 0.56 & 0.02 \\
\hline $1-\mathrm{V}$ & 8.69 & 213.00 & 156.00 & 190.69 & 57.54 & 1.12 & 1.61 & 0.50 & 62 & 3. & 13.07 & 1. & 0.00 & 0 . & 0.01 \\
\hline $2-\mathrm{V}$ & 8.65 & 383.00 & 191.00 & 202.13 & 97.13 & 1.89 & 0.64 & 0 & 70 & 7 & 14 & 2.95 & 0.00 & 0 & 0.02 \\
\hline $3-\mathrm{V}$ & 8.63 & 381.00 & 191.00 & 217.38 & 94.90 & 1. & 0.41 & 0.12 & 70 & 7. & 13.25 & 2.43 & 0.01 & 0 . & 0.02 \\
\hline $4-\mathrm{V}$ & 8.62 & 400.00 & 200.00 & 217.38 & 100.10 & 1. & 0.47 & 0 . & & 7.0 & & 2.43 & 0.00 & 0.81 & 0.02 \\
\hline $5-\mathrm{V}$ & 8.63 & 386.00 & 193.00 & 163.99 & 129.53 & 1.59 & 1.17 & 0.13 & & 6.19 & 18.30 & 12.70 & 0.00 & 0.65 & 0.09 \\
\hline $6-\mathrm{V}$ & 8.60 & 419.00 & 210.00 & 205.94 & 131.90 & 1.77 & 4.37 & 0.16 & 78.28 & 6.12 & 13.64 & 3.89 & 0.00 & 0.55 & 0.02 \\
\hline $7-\mathrm{V}$ & 8.60 & 458.00 & 229.00 & 205.94 & 151.62 & 1.54 & 3.24 & 0.11 & 84.14 & 6.36 & 11.52 & 3.02 & 0.00 & 0.97 & 0.00 \\
\hline $8-\mathrm{V}$ & 8.60 & 385.00 & 192.00 & 171.62 & 123.51 & 2.04 & 4.48 & 0.22 & 73.58 & 6.04 & 14.65 & 2.83 & 0.00 & 0.49 & 0.01 \\
\hline $9-\mathrm{V}$ & 8.09 & 403.00 & 201.00 & 198.32 & 123.57 & 1.85 & 4.58 & 0.22 & 71.67 & 5.90 & 14.43 & 3.38 & 0.00 & 0.50 & 0.01 \\
\hline $10-\mathrm{V}$ & 8.60 & 408.00 & 204.00 & 186.87 & 122.01 & 1.98 & 4.82 & 0.23 & 60.44 & 5.51 & 13.69 & 3.27 & 0.00 & 0.76 & 0.02 \\
\hline S-II & 8.09 & 205.00 & 102.00 & 85.69 & 1.23 & 0.40 & 2.27 & 0.22 & 25.78 & 18.48 & 3.84 & 2.60 & 0.08 & 0.24 & 0.01 \\
\hline S-III & 8.32 & 188.00 & 94.00 & 100.10 & 9.78 & 0.64 & 2.71 & 0.25 & 51.30 & 2.06 & 2.51 & 0.74 & 0.00 & 0.17 & 0.05 \\
\hline S1-IV & 8.59 & 204.00 & 101.00 & 152.55 & 14.39 & 0.45 & 2.10 & 0.07 & 46.65 & 1.91 & 2.59 & 0.89 & 0.00 & 0.43 & 0.01 \\
\hline S2-IV & 8.59 & 197.00 & 98.00 & 152.55 & 14.24 & 0.46 & 1.55 & 0.05 & 51.53 & 2.02 & 2.72 & 0.88 & 0.00 & 0.43 & 0.01 \\
\hline
\end{tabular}

Note: $\mathrm{pH}$ is dimensionless. 


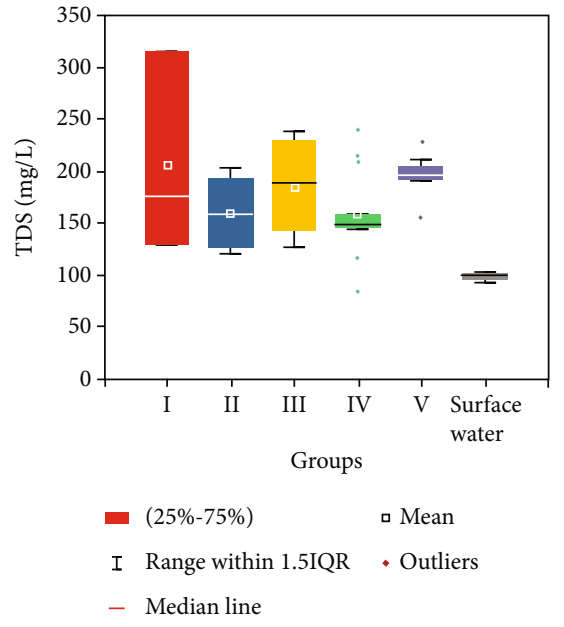

(a)

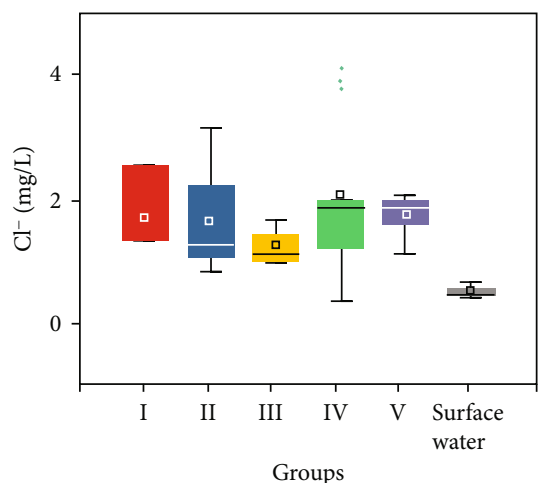

- $(25 \%-75 \%) \quad$ 口 Mean

I Range within 1.5IQR • Outliers

- Median line

(d)

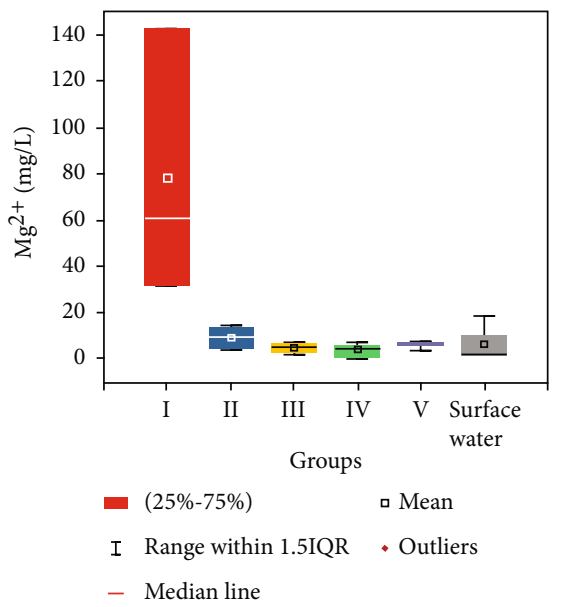

(g)

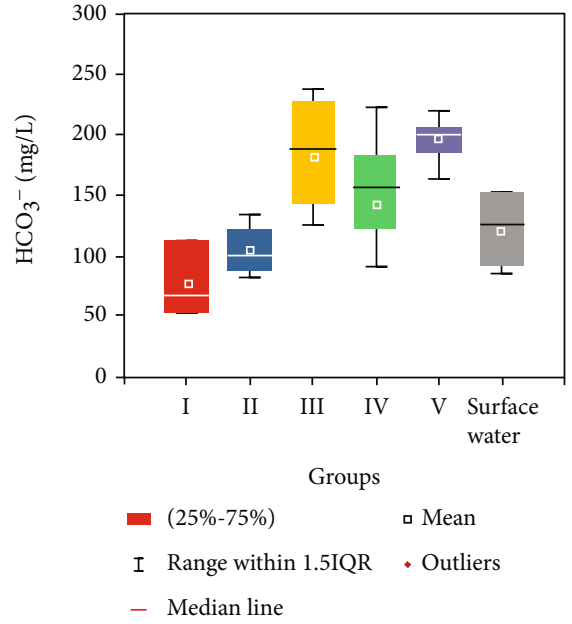

(b)

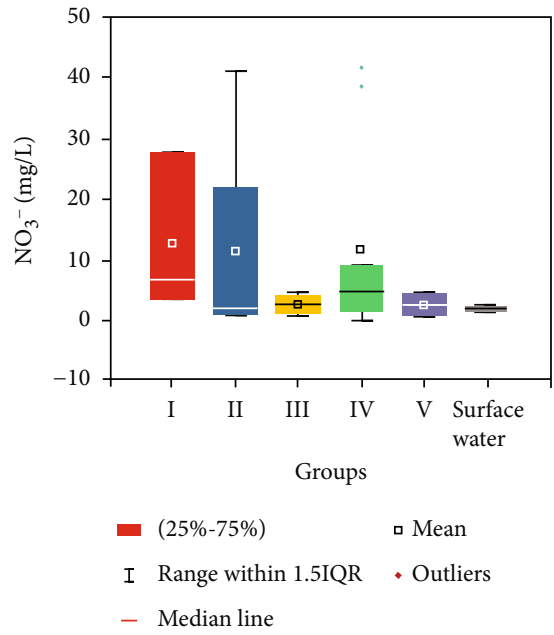

(e)

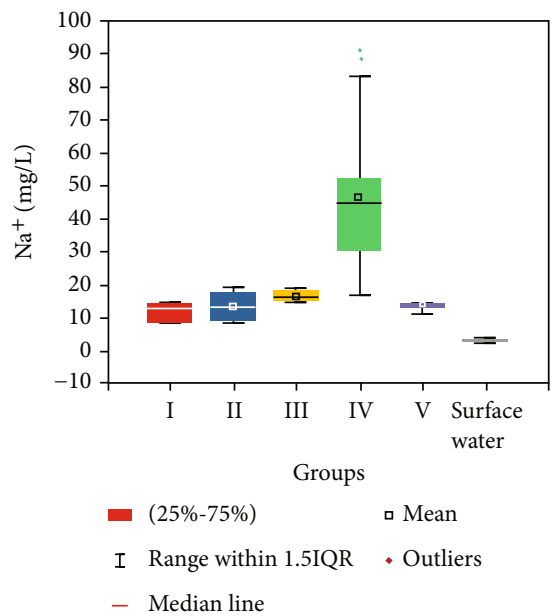

(h)

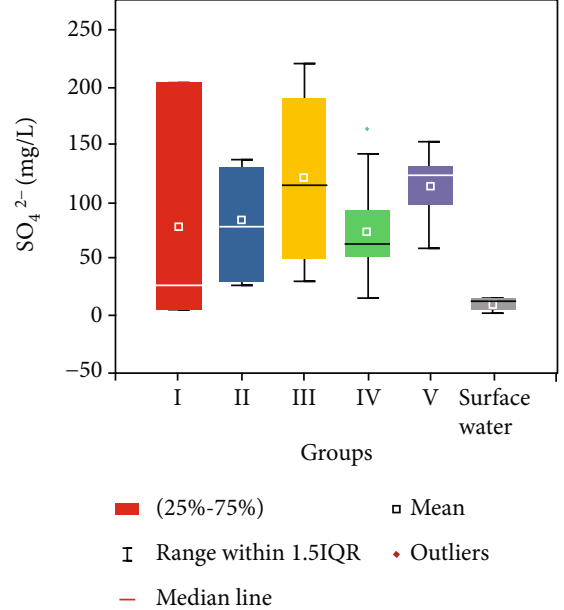

(c)

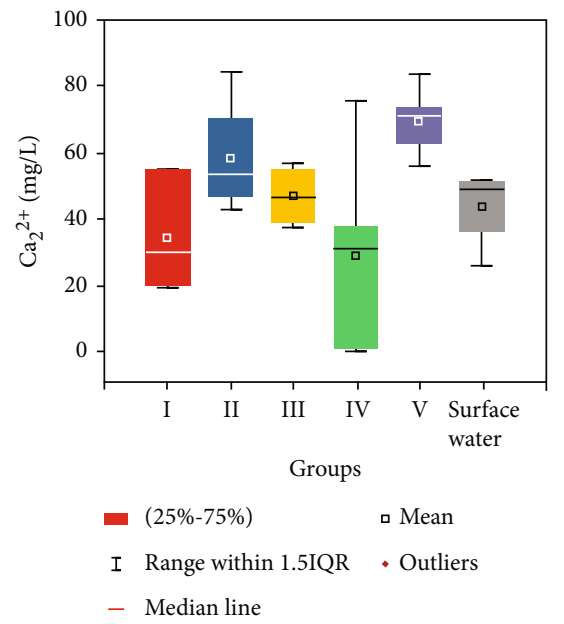

(f)

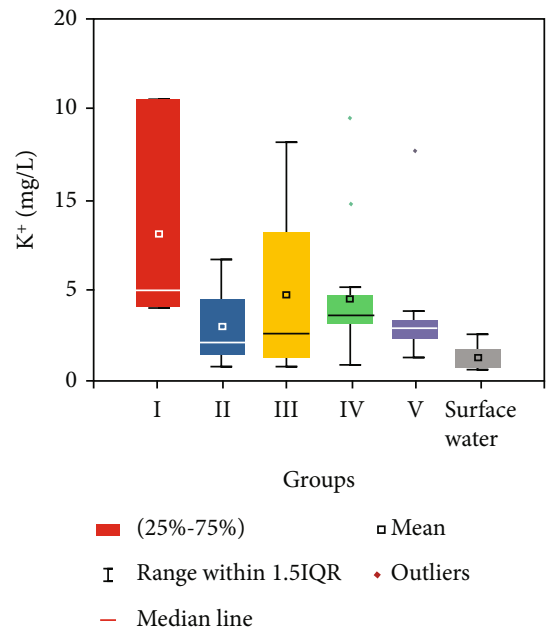

(i)

FIgURE 3: Box diagram of main ion concentration in the study area.

saturation index SI of mineral dissolution through the PHREEQC software, as shown in formula (3). IAP is the active product of mineral water ions, and $K_{\text {ep }}$ represents the equilibrium constant at a certain temperature. If SI is positive, it means that the mineral dissolution is in a saturated state; otherwise, the mineral dissolution is unsaturated. 


$$
\mathrm{SI}=\log \frac{\mathrm{IAP}}{K_{\mathrm{ep}}} .
$$

3.3.3. Cluster Analysis. Cluster analysis is based on multiple analysis target indicators. Find statistics that can measure the degree of similarity between indicators and use them to classify types. A dendrogram classification system is formed based on the degree of similarity between the variables, and only one cluster is left at the end [20].

3.3.4. Principal Component Analysis. The principal component analysis is one of the main multivariate statistical methods for analyzing hydrochemical data, simplifying the data structure by reducing the dimensionality of the research object indicators. The principal component after dimensionality reduction is a linear combination of the original data, compared with the 2-variable scatter diagram, which can only describe the relationship between two variables. The principal component analysis can describe the chemical process of groundwater from a multivariate perspective [21].

3.3.5. Groundwater Quality. The F value method recommended by the "Groundwater Quality Standard of the People's Republic of China" is employed. Evaluate the groundwater quality in the study area. As shown in Table 1, the code divides the quality of groundwater into $\mathrm{I} \sim \mathrm{V}$ categories. Refer to Table 2, first, a single index is scored, and then, according to formulas (4) and (5), the individual index evaluation score $F_{i}$ and the comprehensive evaluation score $F$ are obtained, and the water quality category is obtained [22].

$$
\begin{aligned}
& F=\sqrt{\frac{\bar{F}^{2}+F_{\max }^{2}}{2},} \\
& \bar{F}=\frac{1}{n} \sum_{1}^{n} F_{i} .
\end{aligned}
$$

In the formula, $\bar{F}$ is the average value of each single index score $F_{i}, F_{\max }$ is the maximum value of single index score $F_{i}$, and $n$ is the number of evaluation index items.

\section{Results and Discussion}

4.1. Statistics of Experimental Results. The water chemical indicators analyzed in this study are $\mathrm{pH}, \mathrm{TDS}, \mathrm{EC}, \mathrm{HCO}_{3}{ }^{-}$, $\mathrm{SO}_{4}^{2-}, \mathrm{Cl}^{-}, \mathrm{NO}_{3}{ }^{-}, \mathrm{F}^{-}, \mathrm{Ca}^{2+}, \mathrm{Mg}^{2+}, \mathrm{K}^{+}, \mathrm{Na}^{+}, \mathrm{NH}_{4}^{+}, \mathrm{Fe}$, and $\mathrm{Al}$; the experimental results are listed in Table 3. The time trend of the concentration of main ions is shown in box plot 3.

Figures 3(a)-3(i) show the time changes of TDS, $\mathrm{HCO}_{3}{ }^{-}$, $\mathrm{SO}_{4}{ }^{2-}, \mathrm{Cl}^{-}, \mathrm{NO}_{3}{ }^{-}, \mathrm{Ca}^{2+}, \mathrm{Mg}^{2+}, \mathrm{K}^{+}$, and $\mathrm{Na}^{+}$concentrations during 5 samplings. TDS characterizes the total amount of dissolved components in water and is an important parameter for evaluating water salinity. It can be seen from Figure 3(a) that the average TDS in the samples in April 2021 is the largest. The TDS content in the surface water is lower than the underground water content in the tunnel

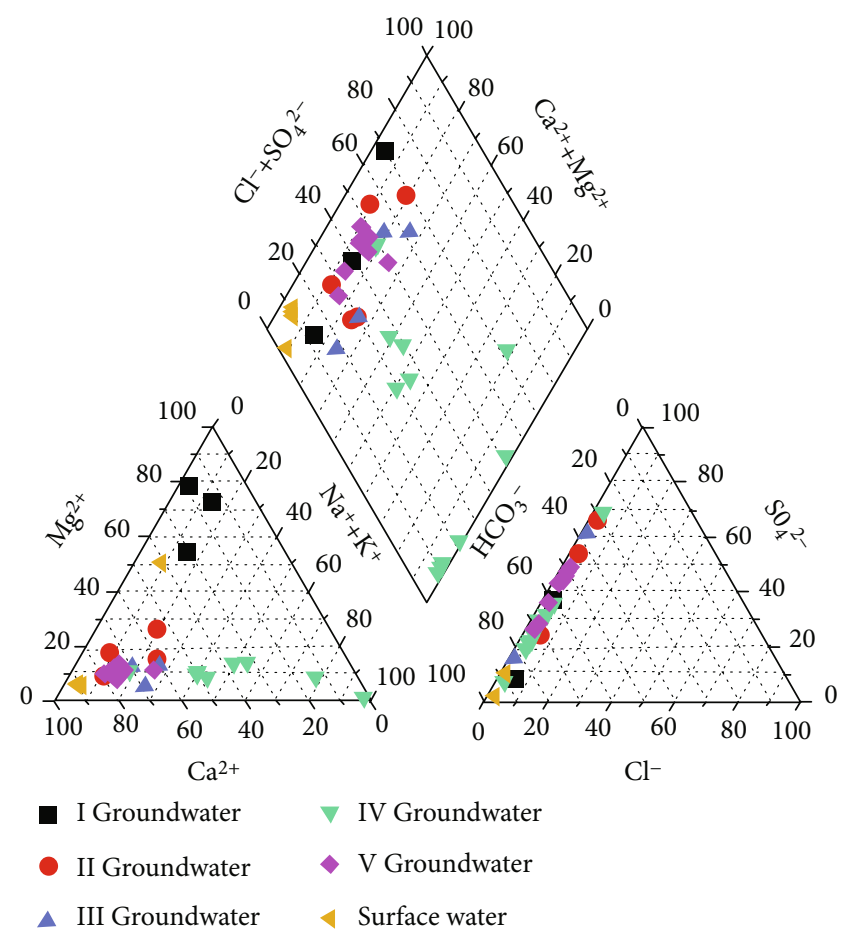

FIgURE 4: Pipper three-line diagram of the study area.

which indicates that after the excavation of the tunnel, the groundwater circulation is accelerated, and the water-rock interaction time increases due to the influence of stratum lithology and construction. $\mathrm{HCO}_{3}{ }^{-}$is the most common anion in the study area, the $\mathrm{HCO}_{3}{ }^{-}$concentration of surface water is much greater than other anions, and this is also the characteristic of ion content in natural river water in karst areas, which is related to the widespread distribution of carbonate rocks. $\mathrm{Ca}^{2+}, \mathrm{Mg}^{2+}, \mathrm{K}^{+}$, and $\mathrm{Na}^{+}$in the karst zone mainly come from the dissolution of carbonate rocks, silicate rocks, and salt rocks. It is also a common cation in karst areas; the content of cations in different groups of groundwater varies greatly, which may be affected by the different intensity of water and rock action. The geochemical behavior of $\mathrm{Cl}^{-}$is simple, it does not participate in the oxidationreduction reaction and mainly comes from atmospheric precipitation and salt rock [23], $\mathrm{NO}_{3}{ }^{-}$is a common pollutant in surface water, and $\mathrm{SO}_{4}{ }^{2-}, \mathrm{Cl}^{-}$, and $\mathrm{NO}_{3}{ }^{-}$all have abnormal values in the underground water in the tunnel. The surface water, on the other hand, has no abnormal value and very low content, indicating that the natural surface water in the study area is of good quality and less polluted, and groundwater is more sensitive to tunnel construction.

4.2. Water Chemistry Characteristics. As can be seen from Figure 4 , the dominant cations of the water samples of group I are $\mathrm{Mg}^{2+}$, and the dominant cations of the water samples of other groups are $\mathrm{Ca}^{2+}, \mathrm{K}^{+}$, and $\mathrm{Na}^{+}$. The anions of all samples are distributed on the $\mathrm{HCO}_{3}{ }^{-}$side; the overall performance is $\mathrm{HCO}_{3}{ }^{-}>\mathrm{SO}_{4}{ }^{2-}>\mathrm{Cl}^{-}$. Groundwater and surface water of groups I, II, III, and V are distributed on the upper left side of the diamond shape, and the main types of water chemistry are $\mathrm{HCO}_{3}-\mathrm{Ca} \cdot \mathrm{Mg}$ type and $\mathrm{SO}_{4} \cdot \mathrm{Cl}-\mathrm{Ca} \cdot \mathrm{Mg}$ type. 


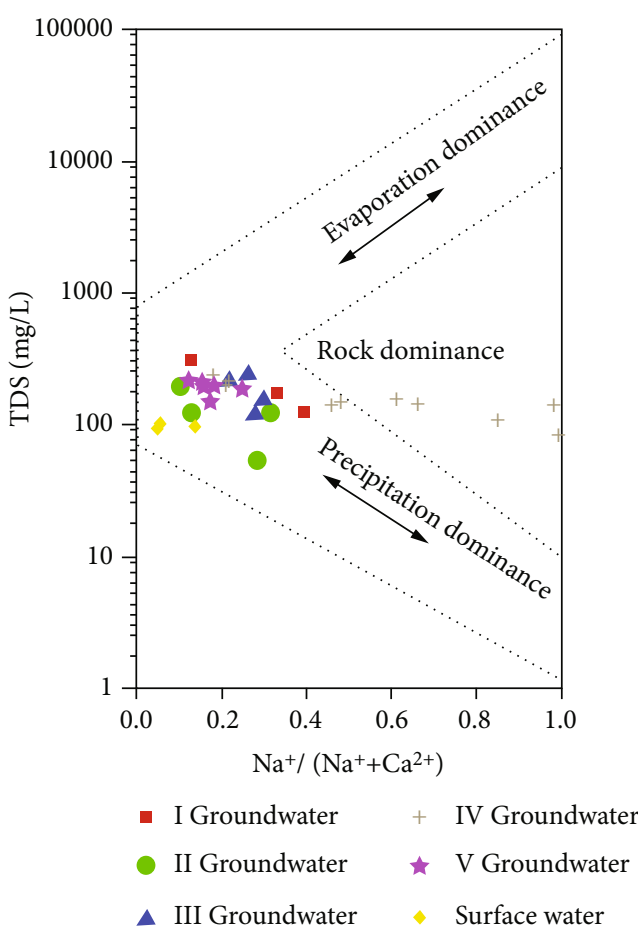

(a)

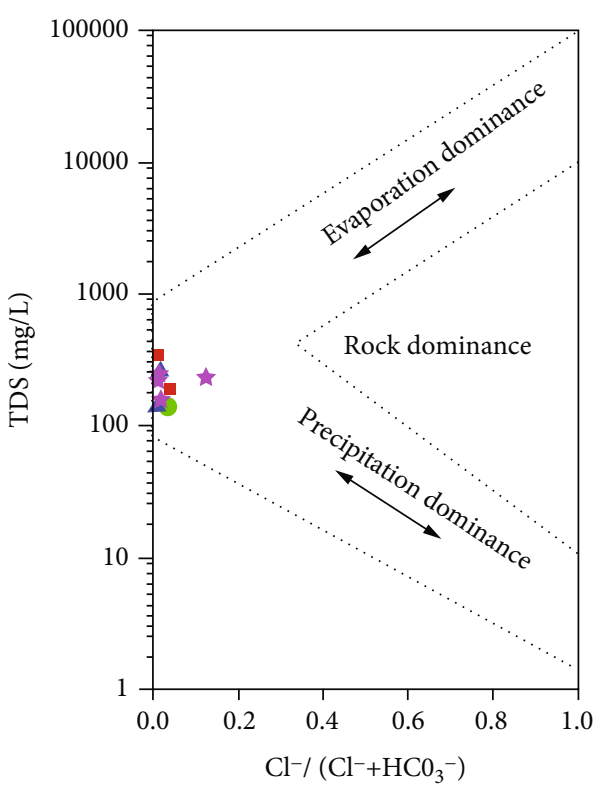

(b)

FIgURe 5: Gibbs model of the study area.

The groundwater of group IV is distributed in the middle and lower right side of the rhombus, and the water chemistry type is mainly $\mathrm{HCO}_{3}-\mathrm{Na} \cdot \mathrm{K}$ type. The surface water sample is carbonate calcium water, and the sampling point is in the downstream of the surface river, which is consistent with the hydrochemical type of spring point at the tunnel outlet in the geological exploration stage before construction. The water samples of group IV and group V were taken in March and April 2021, respectively. They are in the dry season; the water samples of group IV are mainly from YK38+621 to YK43+730, interspersed with coal-measure strata; it can be seen that the water chemical phase transition of the water samples of group IV is related to the formation lithology.

As shown in Figure 5, groundwater and surface water samples from various periods are distributed in the middle of the Gibbs model. It reveals that rock weathering controls the chemical composition of the water in the study area, and the effects of atmospheric precipitation, evaporation, and crystallization are negligible. Water-rock interaction is the main hydrogeochemical process in the study area.

4.3. Relationship between Main Ions in Groundwater. The relationship of ion ratio in the water further illustrates the water-rock interaction in the study area. In karst areas, carbonate rocks are generally the main source of $\mathrm{HCO}_{3}{ }^{-}, \mathrm{Ca}^{2+}$, and $\mathrm{Mg}^{2+}$ in the study area. In Figures 6(a) and 6(b), the 4 samplings of surface river water all fall on the $1: 1$ line, which is consistent with the weathering and dissolution of carbonate rocks in the natural water bodies of the study area. Most of the groundwater samples of groups I, II, and V are located in the upper part of the $1: 1$ line; it shows that in addition to typical carbonate dissolution such as calcite and dolomite, other minerals are containing $\mathrm{Ca}^{2+}$ dissolved in groundwater. The equivalent ratio of $\mathrm{Ca}^{2+}$ to $\mathrm{Mg}^{2+}$ is usually used to explain the source of $\mathrm{Ca}^{2+}$, except for the first group of water samples; the equivalent ratio of $\mathrm{Ca}^{2+}$ to $\mathrm{Mg}^{2+}$ is greater than $2: 1$; it shows that the dissolution of gypsum and sulfate rock minerals has a great contribution to $\mathrm{Ca}^{2+}[24] ; \mathrm{Ca}^{2+}$ in the study area is affected by the dissolution of carbonate rock, silicate rock, gypsum, etc. However, the intensities of the interaction between carbonate rock and gypsum are different in different sampling periods.

It can be seen from Figure 6(c) that the equivalent ratio of $\mathrm{Ca}^{2+}, \mathrm{Mg}^{2+}$, and $\mathrm{HCO}_{3}^{-}$in the groundwater and surface water samples of groups $\mathrm{I}, \mathrm{II}$, and $\mathrm{V}$ is greater than $1: 1$; it depicts that in addition to the $\mathrm{HCO}_{3}{ }^{-}$produced by the reaction of $\mathrm{H}_{2} \mathrm{CO}_{3}$ in the carbonate rock, other anions are needed to balance it; the anion in groundwater and surface water next to $\mathrm{HCO}_{3}{ }^{-}$is $\mathrm{SO}_{4}{ }^{2-}$. $\mathrm{SO}_{4}{ }^{2-}$ equivalent accounted for $51.2 \%$ of the anions in group I, $45.8 \%$ in group II, $44.0 \%$ in group III, $36.5 \%$ in group IV, $41.5 \%$ in group V, and $9.05 \%$ in surface water. It can be seen that $\mathrm{SO}_{4}{ }^{2-}$ cannot be neglected in the interaction between groundwater and surrounding rocks, and carbonic acid is dominant in surface water. Since the Tongzi Tunnel is a mountain tunnel with a large buried depth, there are no human settlements on the overlying, so industrial activities will not affect $\mathrm{SO}_{4}{ }^{2-}$. It is preliminarily judged that $\mathrm{SO}_{4}{ }^{2-}$ comes from gypsum and sulfate rock and special formations. The equivalent ratio of $\mathrm{Ca}^{2+}, \mathrm{Mg}^{2+}$, and $\mathrm{HCO}_{3}^{-}$in the water samples of groups III and IV is less than $1: 1$, which means that the cations are mainly balanced by $\mathrm{HCO}_{3}^{-}$. 


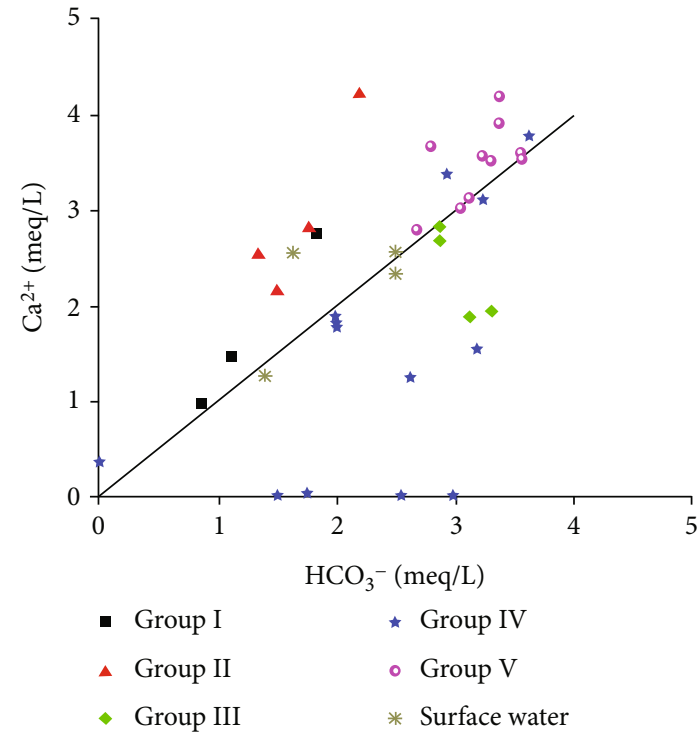

(a)

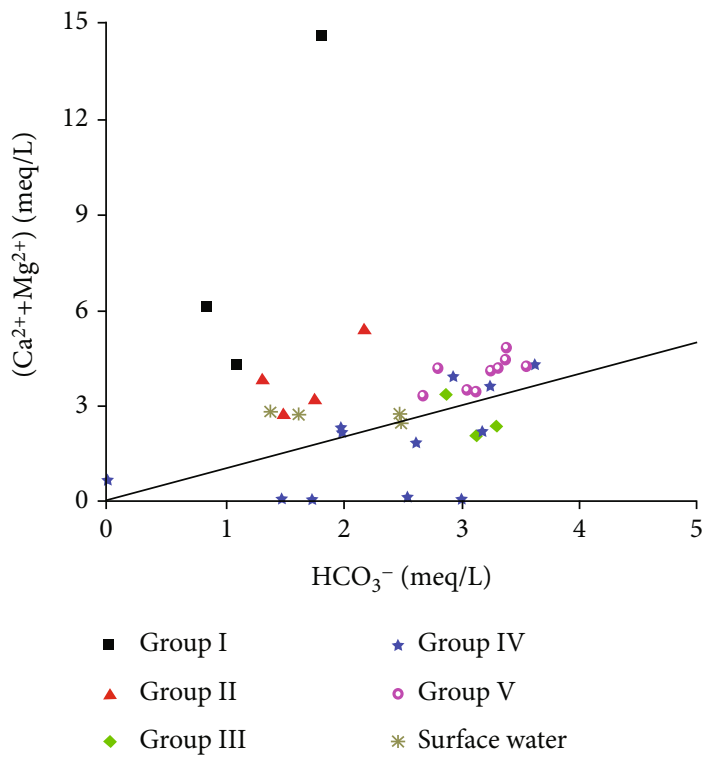

(c)

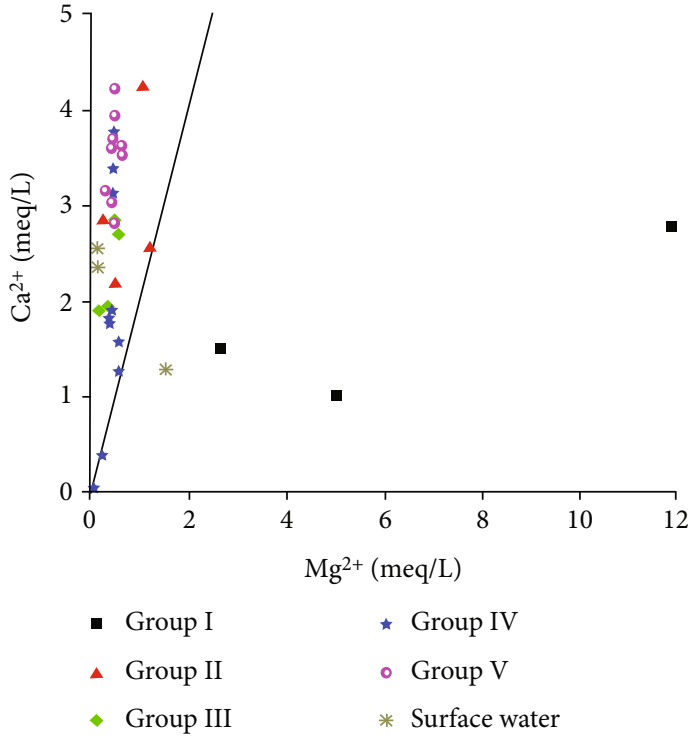

(b)

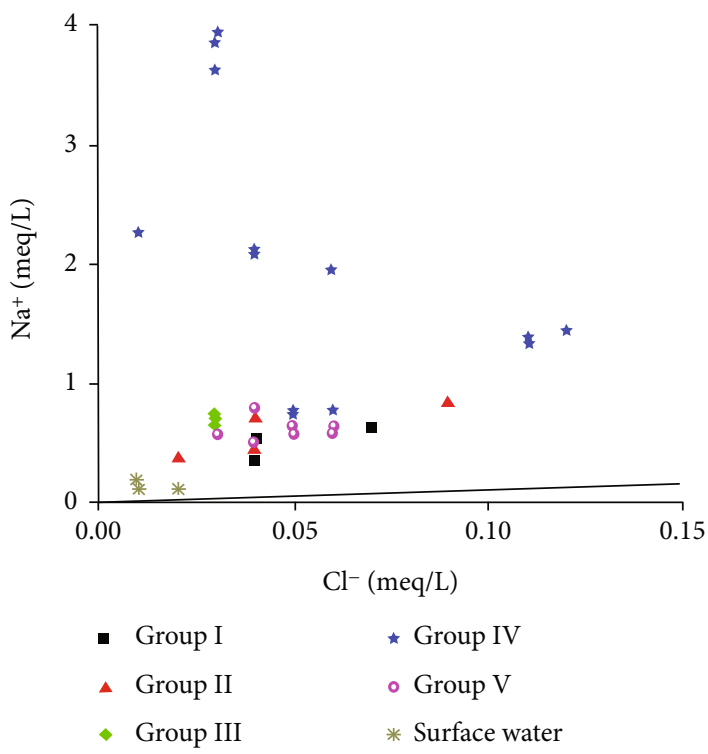

(d)

Figure 6: Ratio of main ions in the study area.

If $\mathrm{Na}^{+}$and $\mathrm{Cl}^{-}$mainly come from the dissolution of salt rock, the equivalent ratio of $\mathrm{Na}^{+}$and $\mathrm{Cl}^{-}$is $1: 1$. When the ratio of $\mathrm{Na}^{+}$to $\mathrm{Cl}^{-}$is greater than $1: 1$, silicate rocks contribute more to $\mathrm{Na}^{+}$[25]. From Figure 6(d), the surface water sample is closest to the $1: 1$ line, and there is a large excess of $\mathrm{Na}^{+}$in the groundwater since the atmospheric precipitation in the study area has no obvious control effect on the source of ions; then, the sodium-containing silicate rock and cation exchange may be the main cause of $\mathrm{Na}^{+}$.

4.4. Cation Exchange. As can be seen from Figures 7(a) and 7 (b), about $77 \%$ of the water samples of group IV are on the $-1: 1$ line, and CAI1 and CAI2 are both negative, which shows that reverse cation exchange occurred in the IV water sample. The dissolved $\mathrm{Ca}^{2+}$ and $\mathrm{Mg}^{2+}$ in the carbonate rock in the groundwater exchanged with the $\mathrm{Na}^{+}$and $\mathrm{K}^{+}$in the surrounding rock of the tunnel. The adsorption of $\mathrm{Ca}^{2+}$ and the release of $\mathrm{Na}^{+}$explain the increase of $\mathrm{Na}^{+}$in the IV water sample, which also leads to changes in the chemical composition of the water. The lithology of group IV mainly includes coal-measure strata, carbonaceous mudstone, and mudstone intercalated with limestone. There are silicate minerals and clay minerals such as feldspar and quartz in these rock formations. According to the geological survey before the construction of the tunnel, the chemical type of underground aquifer water in the coal tunnel of Tuanyuan Coal Mine is sulfate potassium sodium water. It is speculated that $\mathrm{SO}_{4}{ }^{2-}$ comes from sulfate rock and gypsum, and $\mathrm{Na}^{+}$ and $\mathrm{K}^{+}$come from reverse cation exchange. After the construction of the tunnel, the frequent exchange and flow of 


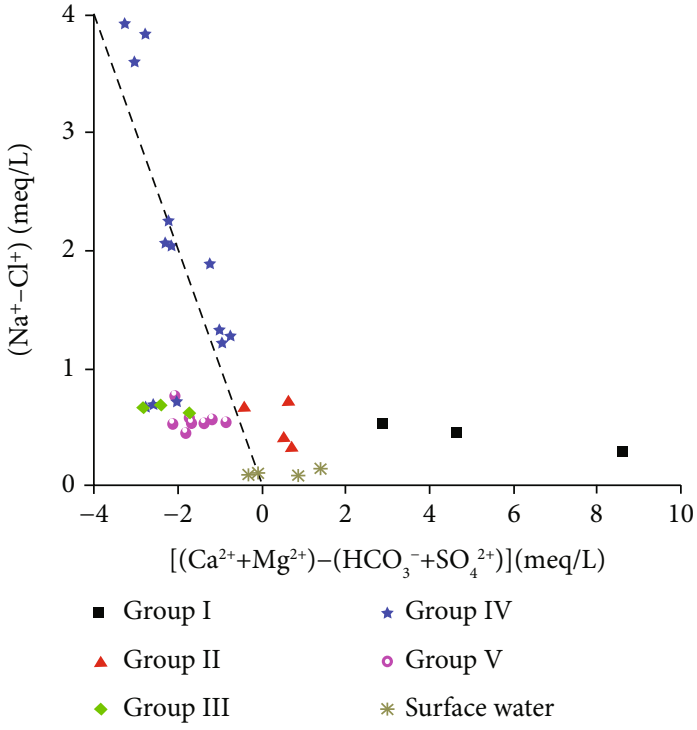

(a)

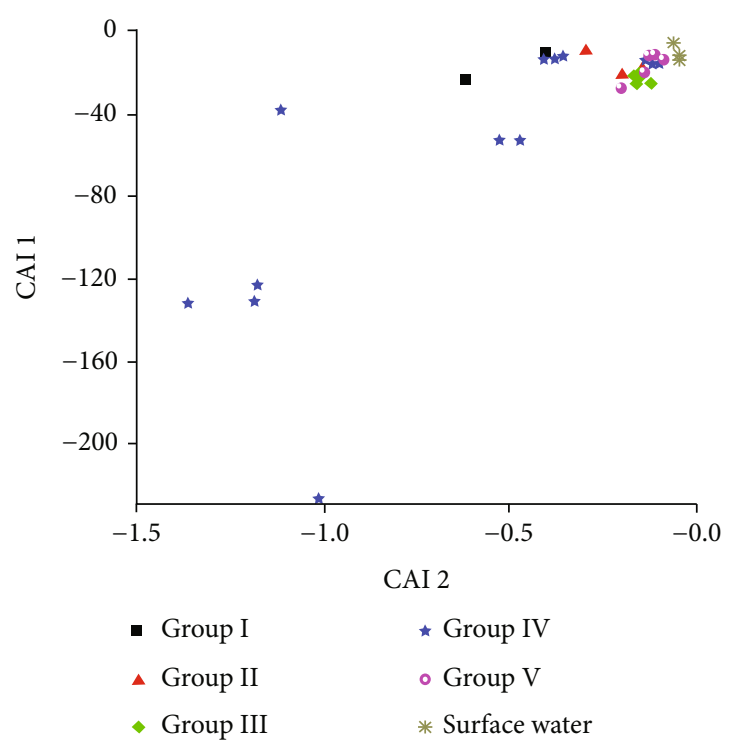

(b)

FIgURe 7: Cation reverse exchange.

groundwater accelerate this cation exchange behavior. According to the size of the chlor-alkali index, the intensity of cation adsorption alternate action in the groundwater of group IV is greater than that of other groups of water samples, and the ion exchange intensity of groundwater is greater than that of surface water.

4.5. Hydrogeochemical Simulation. The main ion genesis mechanisms in the study area are water-rock interaction, as well as rock weathering and dissolution. To ascertain the dissolution and precipitation processes of the major minerals influencing groundwater chemistry [26]. Alum, calcite, dolomite, fluorite, gypsum, rock salt, hematite, and dissolved carbon dioxide saturation index were calculated using PHREEQC software. The scatter plot of saturation index and TDS is shown in Figure 8.

It can be seen that the saturation index of alunite in the study area is less than 0 , which is unsaturated; the saturation index of alunite in surface river water is the smallest. The SI value of gypsum containing $\mathrm{SO}_{4}{ }^{2-}$ is also less than 0 , which verifies the hypothesis that $\mathrm{SO}_{4}{ }^{2-}$ in water comes from sulfate minerals and gypsum. In karst areas, pyrite in coalmeasure strata also has higher $\mathrm{SO}_{4}{ }^{2-}$. The saturation index of mostly calcite and dolomite is greater than 0 . Also, in a saturated state, only a small part of the water samples of group IV is unsaturated. Due to the independence of the SI value of calcite and dolomite from TDS, the supersaturated carbonate minerals produce precipitation and contribute chemical components to the groundwater [27, 28].

The physical and chemical properties of fluorite and calcite are indistinguishable. In addition to the replenishment of surface runoff and infiltration by atmospheric precipitation, the $\mathrm{F}^{-}$in surface water and groundwater mainly comes from the dissolution of fluorite. It can be seen from Figure $8(\mathrm{~d})$ that the dissolution of fluorite in the study area is unsaturated. The saturation index of hematite in most water samples is greater than 0 , indicating that the hematite has been dissolved and saturated. Hematite and pyrite are the main sources of $\mathrm{Fe}$ in groundwater. After the tunnel is excavated, the original aquifer's closed state is broken, and the $\mathrm{CO}_{2}$ may come from the dissolution of $\mathrm{CO}_{2}$ in the atmosphere. Figure 8 shows that as $\mathrm{CO}_{2}$ dissolves, the $\mathrm{pH}$ value decreases and produces carbonic acid to participate in water-rock action [29].

4.6. Cluster Analysis. Figure 9 indicates that the water samples in the study area can be divided into 7 categories. The first cluster is dominated by group IV water, including 3 water samples near the entrance of the tunnel at ZK34 +715 during the dry season and 5 water samples at the exit of the tunnel between YK38+621 and YK43+025, respectively. The lithology of the aquifer group is dominated by limestone intercalated with carbonaceous mudstone, carbonaceous mudstone, and coal-measure strata representing the weathering and dissolution of sulfate rock and ion exchange. The second cluster is the water samples of group I ZK34+715 in the wet season. The third cluster includes surface river water and groundwater in groups 1-III, $1-\mathrm{V}$, 2-II, and 8-IV, representing the chemical characteristics of natural water bodies in the study area. The fourth cluster is the water sample of YK43+650 in the abundant and dry water periods. The fifth cluster is dominated by water samples of group V, concentrated between YK43+613 and YK43+730; the lithology of the aquifer group is dominated by limestone and coal-measure strata. The reverse cation exchange behavior of this group of water samples is weaker than that of group IV, due to the difference in stratum lithology. Various minerals such as calcite and other carbonate rocks, gypsum, and silicate rocks are dissolved and precipitated. The sixth and seventh clusters have only one water sample, and the water chemistry characteristics are relatively independent. 

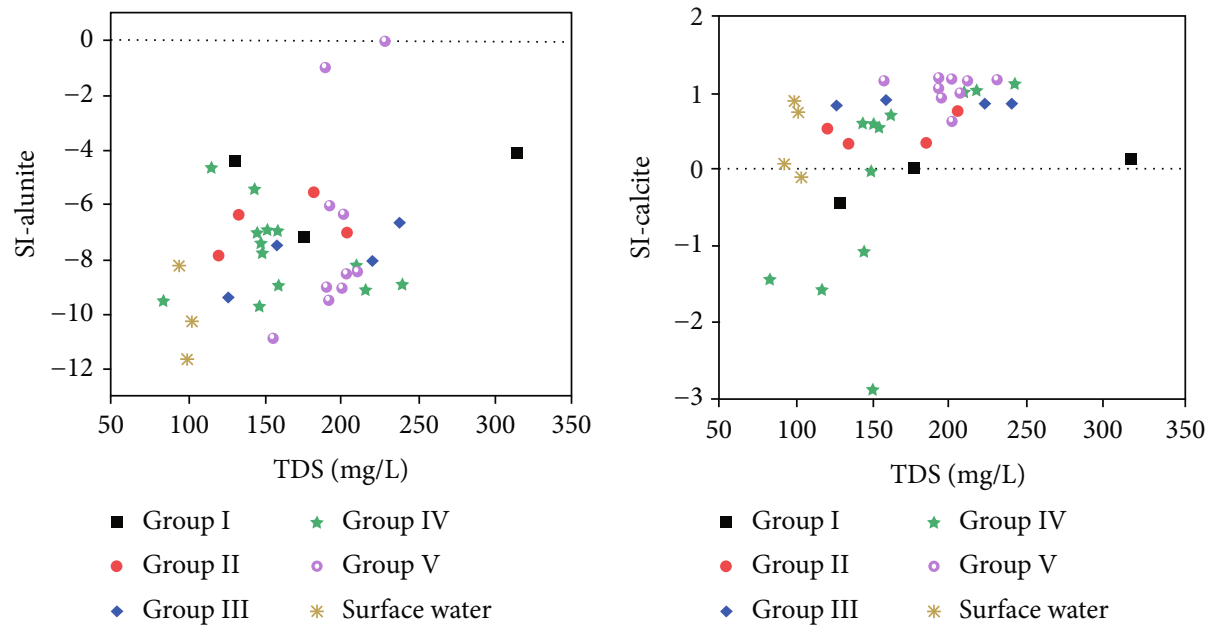

$\begin{array}{ll}\text { - Group I } & \text { * Group IV } \\ \text { - Group II } & \circ \text { Group V } \\ \text { - Group III } & * \text { Surface water }\end{array}$

(a)

(b)
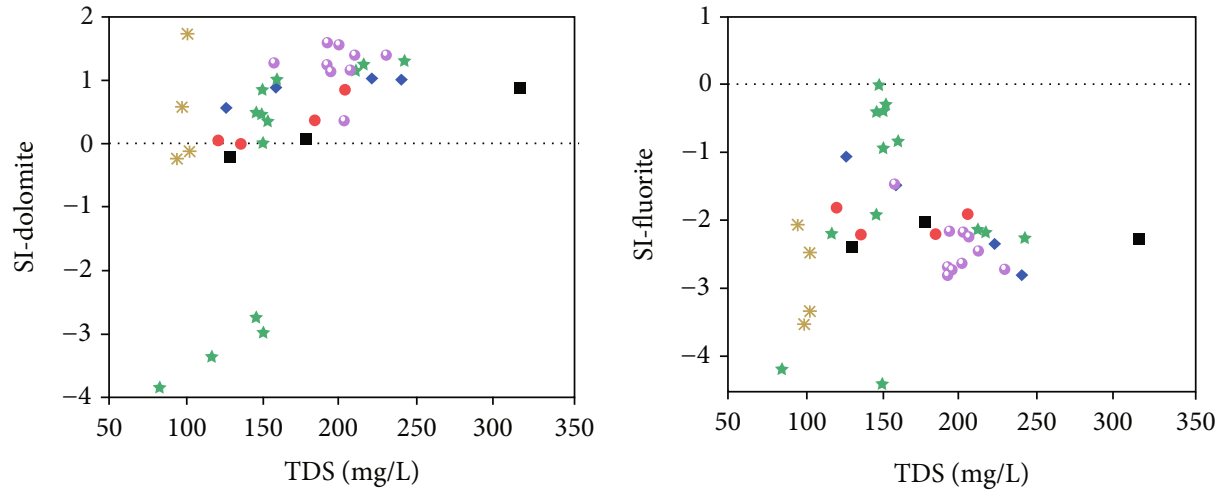

- Group I * Group IV

- Group II ○ Group V

- Group III * Surface water

(c)

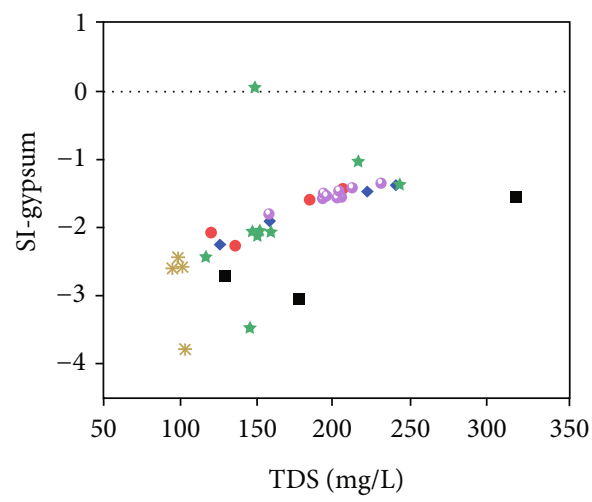

- Group I * Group IV

- Group II • Group V

- Group III * Surface water

(d)

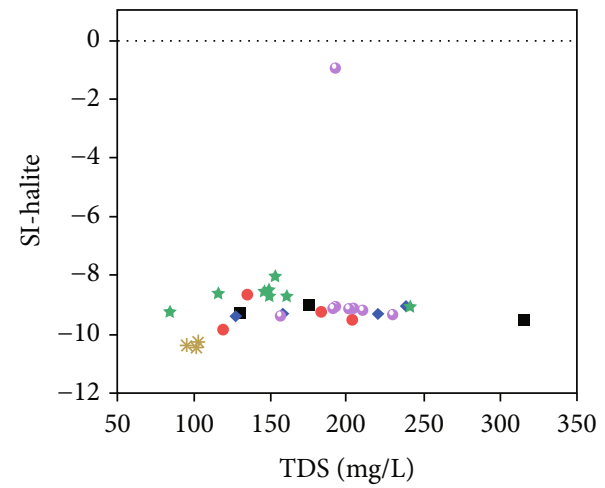

- Group I * Group IV

- Group II 。Group V

- Group III * Surface water

- Group I * Group IV

- Group II 。Group V

- Group III * Surface water

(e)

(f)

Figure 8: Continued. 


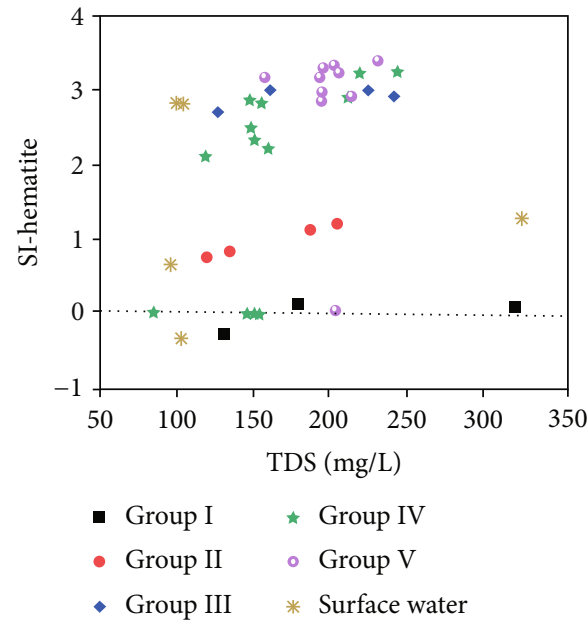

(g)

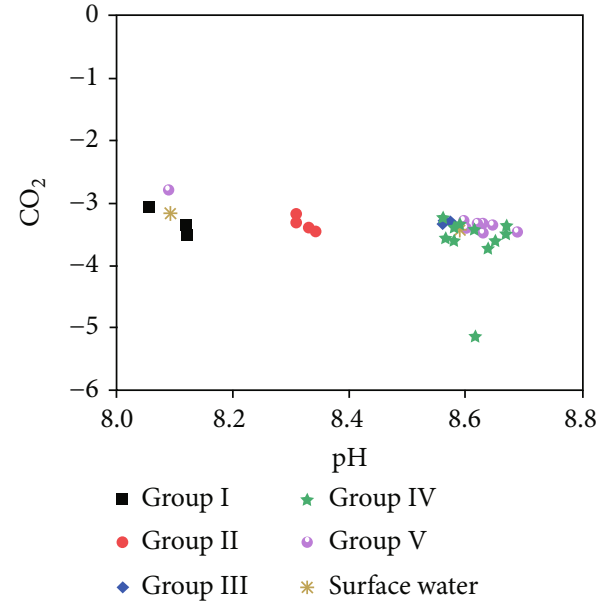

(h)

Figure 8: Saturation index of main minerals.

According to the clustering results, surface river water has a lower impact on groundwater, and the groundwater is consistent with the potassium-sodium water chemistry of the sulfate rock drilled in the Tuan Yuan coal mine (coal formation) before construction. It shows that the karst fissure pipeline is relatively developed in fault and goaf. Under the disturbance of tunnel construction and the action of water pressure, the groundwater in the Tuanyuan coal mine boundary mixed with bedrock fissure water into the tunnel.

4.7. Principal Component Analysis. According to the cluster analysis results, the first, third, and fifth clusters with the most samples were chosen for principal component analysis as shown in Figure 10. The KMO value of the sample passed the test. Figures 10 (a) and 10(b) are the load distribution diagrams of the three principal components of the first type of samples. The total variance contribution rate was $82.56 \%$, and the variance contribution rate of principal component 1 was $37.46 \%$, which showed a strong positive correlation with $\mathrm{Ca}^{2+}, \mathrm{Mg}^{2+}$, and $\mathrm{Fe}$ and a strong negative correlation with $\mathrm{Na}^{+}, \mathrm{Al}$, and $\mathrm{pH}$. The variance contribution rate of principal component 2 is $27.82 \%$, which is positively correlated with EC, TDS, $\mathrm{HCO}_{3}{ }^{-}$, and $\mathrm{NH}_{4}{ }^{+}$. The variance contribution rate of principal component 3 is $17.28 \%$, which is positively correlated with $\mathrm{K}^{+}, \mathrm{Cl}^{-}, \mathrm{F}^{-}$, and $\mathrm{NO}_{3}{ }^{-}$. It can be seen that the aquifer originally contained more $\mathrm{Ca}^{2+}$ and $\mathrm{Mg}^{2+}$. The excavation of the tunnel opens the closed coal-measure aquifer and causes the oxidation-reduction reaction of minerals such as pyrite in the coal-measure strata. Therefore, the Fe load value is higher, and because it is negatively correlated or not correlated with $\mathrm{Na}^{+}$and $\mathrm{HCO}_{3}{ }^{-}$. It indicates that the carbonate rock is saturated with dissolution and $\mathrm{Ca}^{2+}$ has other sources, which should be reversed in cation adsorption alternately.

Figures $10(\mathrm{c})$ and $10(\mathrm{~d})$ are the three principal component loading distribution diagrams of the third cluster sample. The variance contribution rate of principal component 1 is $45.18 \%$, which shows a strong positive correlation with TDS, $\mathrm{SO}_{4}{ }^{2-}, \mathrm{Cl}^{-}, \mathrm{F}^{-}$, and $\mathrm{Na}^{+}$. The variance contribution rate

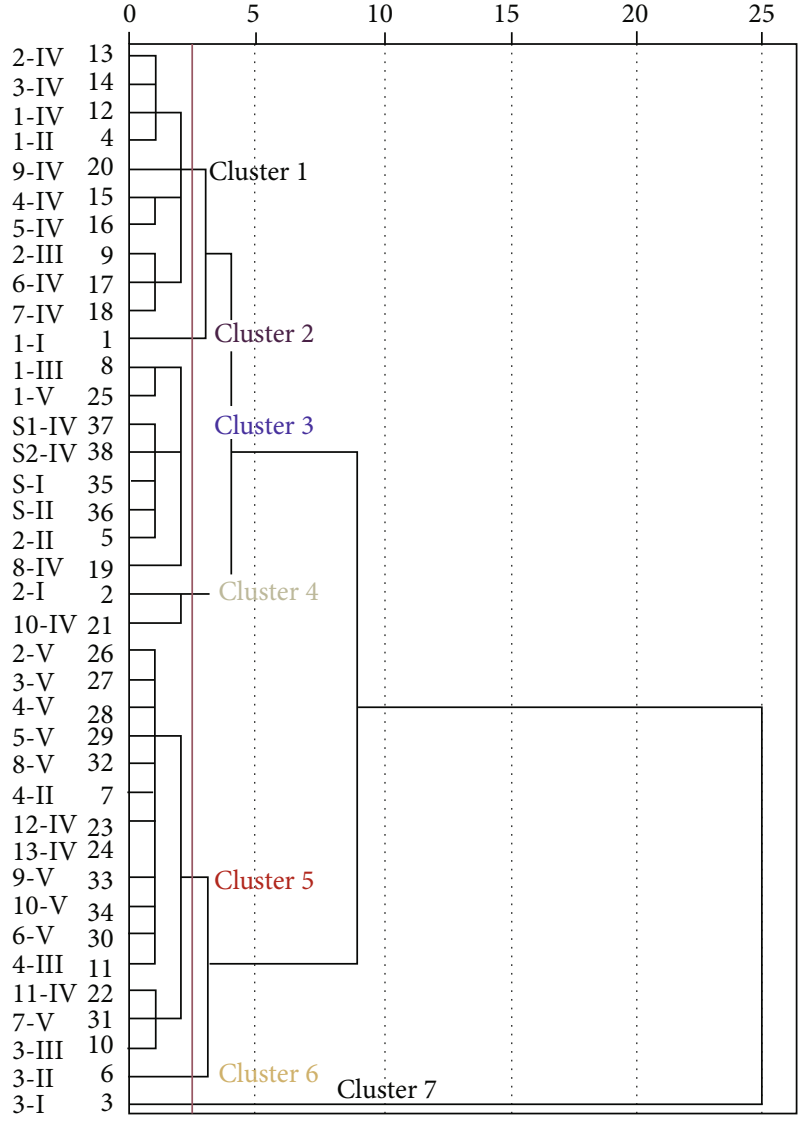

Figure 9: Sample clustering diagram.

of principal component 2 is $22.63 \%$, which is positively correlated with $\mathrm{Ca}^{2+}$ and negatively correlated with $\mathrm{Mg}^{2+}$ and $\mathrm{K}^{+}$. The variance contribution rate of principal component 3 is $16.56 \%$, which shows a strong positive correlation with $\mathrm{NO}_{3}{ }^{-}$and $\mathrm{NH}_{4}{ }^{+}$. It shows that the water-rock action in this type of water sample is the dissolution of sulfate rock and salt rock. $\mathrm{Cl}^{-}$has stable chemical characteristics, mainly from atmospheric precipitation. The surface river water and the 


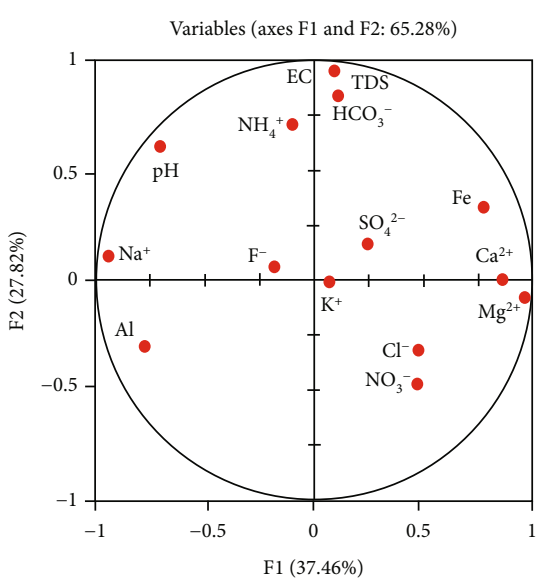

(a)

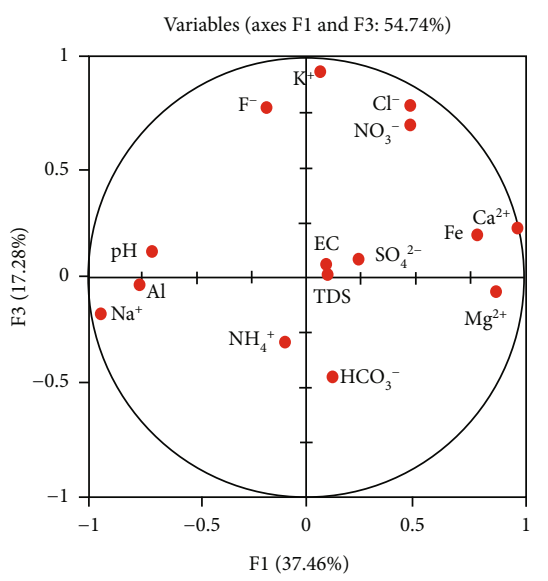

(b)

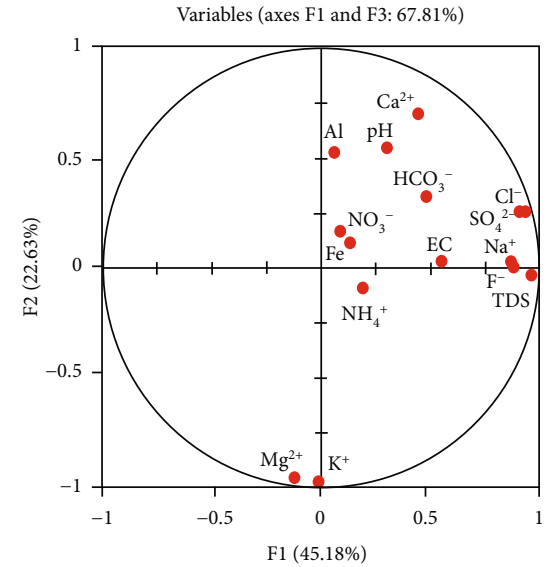

(c)

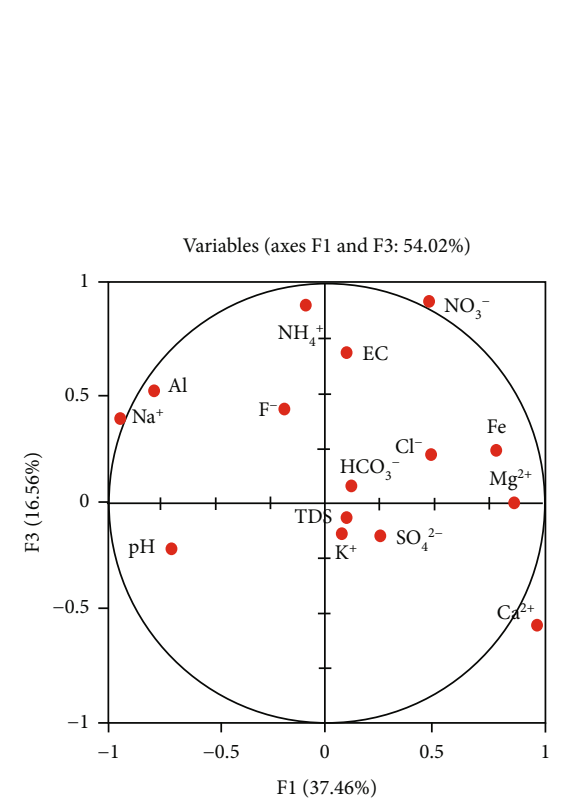

(d)

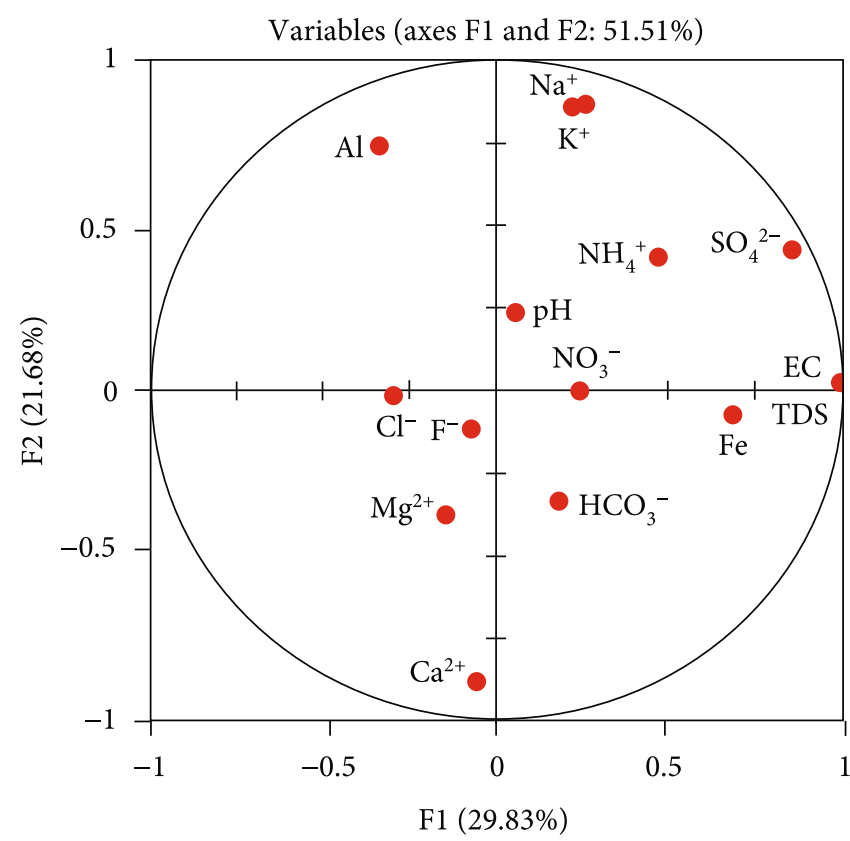

(e)

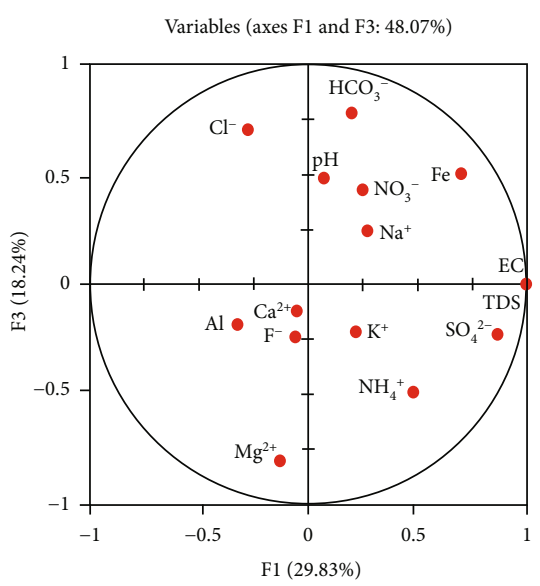

(f)

Figure 10: Principal component analysis results. 
TABLE 4: Water quality evaluation results in the study area.

\begin{tabular}{|c|c|c|c|c|c|c|c|c|}
\hline Sample number & $F$ value & Quality type & Sample number & $F$ value & Quality type & Sample number & $F$ value & Quality type \\
\hline $1-\mathrm{I}$ & 6.2 & IV & $3-I V$ & 10.5 & $\mathrm{~V}$ & $3-\mathrm{V}$ & 6.1 & IV \\
\hline $2-\mathrm{I}$ & 3.1 & III & $4-I V$ & 6.3 & IV & $4-\mathrm{V}$ & 6.1 & IV \\
\hline $3-\mathrm{I}$ & 6.3 & IV & $5-\mathrm{IV}$ & 6.1 & IV & $5-\mathrm{V}$ & 6.1 & IV \\
\hline $1-\mathrm{II}$ & 10.1 & $\mathrm{~V}$ & 6-IV & 6.2 & IV & $6-\mathrm{V}$ & 6.2 & IV \\
\hline 2-II & 3.0 & III & 7-IV & 6.2 & IV & $7-\mathrm{V}$ & 6.2 & IV \\
\hline 3 -II & 3.1 & III & 8-IV & 6.1 & IV & $8-\mathrm{V}$ & 6.1 & IV \\
\hline 4 -II & 6.1 & IV & 9-IV & 10.3 & $\mathrm{~V}$ & $9-\mathrm{V}$ & 6.0 & IV \\
\hline $1-\mathrm{III}$ & 6.2 & IV & $10-I V$ & 6.2 & IV & $10-\mathrm{V}$ & 6.2 & IV \\
\hline 2-III & 6.2 & IV & $11-I V$ & 6.2 & IV & S-I & 3.0 & III \\
\hline 3-III & 6.2 & IV & $12-\mathrm{IV}$ & 6.2 & IV & S-II & 1.0 & II \\
\hline 4-III & 6.2 & IV & $13-I V$ & 6.2 & IV & S1-IV & 6.1 & IV \\
\hline 1-IV & 10.5 & $\mathrm{~V}$ & $1-\mathrm{V}$ & 6.1 & IV & S2-IV & 6.1 & IV \\
\hline 2-IV & 10.5 & $\mathrm{~V}$ & $2-\mathrm{V}$ & 6.1 & IV & & & \\
\hline
\end{tabular}

groundwater of this group are recharged and infiltrated by atmospheric precipitation and are characterized by natural hydrogeochemical effects.

Figures 10(e) and 10(f) are the load distribution diagrams of the three principal components of the fifth cluster of samples. The variance contribution rate of principal component 1 is $29.83 \%$, which shows a strong positive correlation with EC, TDS, $\mathrm{SO}_{4}{ }^{2-}$, and $\mathrm{Fe}$. The variance contribution rate of principal component 2 is $21.68 \%$, which is positively correlated with $\mathrm{Na}^{+}, \mathrm{K}^{+}$, and $\mathrm{Al}$ and strongly negatively correlated with $\mathrm{Ca}^{2+}$. The variance contribution rate of principal component 3 is $18.24 \%$, which is positively correlated with $\mathrm{HCO}_{3}{ }^{-}$and $\mathrm{Cl}^{-}$and strongly negatively correlated with $\mathrm{Mg}^{2+}$. The three main components of this type of groundwater have a low variance contribution rate and large differences, and the water chemical composition is influenced by multiple water-rock interactions.

4.8. Groundwater Quality. According to the evaluation criteria and methods, the water quality category of the study area is obtained. As shown in Table 4, the best water quality is the surface river water of group S-II Grade II. There are 4 groups for Grade III water quality, 28 groups for Grade IV water quality at most, accounting for $73.6 \%$, and there are 5 groups for Grade $\mathrm{V}$ water quality. The worst water quality is the 4 groups of water samples near the ZK34+715 section, which are caused by high concentrations of $\mathrm{NO}_{3}{ }^{-}$and $\mathrm{F}^{-}$, and a group of water samples of the $\mathrm{YK} 43+025$ section, due to high $\mathrm{F}^{-}$concentration which is derived from $\mathrm{Ca}_{2} \mathrm{~F}$ dissolution. Since $\mathrm{NO}_{3}{ }^{-}$has no known lithological source, there is almost no agricultural activity over the tunnel. During the construction period, the sewage outside the tunnel is also strictly prohibited to enter the tunnel. Therefore, the human activities represented by $\mathrm{NO}_{3}{ }^{-}$will pollute the groundwater; it is most likely to come from tunnel construction residues.

The water quality type of groundwater in the coal stratigraphic section is mainly IV water, and the factors determining the water quality category are $\mathrm{Fe}$ and $\mathrm{pH}$, and the water quality is influenced by iron-bearing minerals. Conventional ions such as $\mathrm{SO}_{4}{ }^{2-}, \mathrm{K}^{+}$, and $\mathrm{Na}^{+}$in coal aquifers have little effect on water quality. The $F$ value method highlights the maximum pollution factors, and the analysis of pollution sources is more targeted than other groundwater quality evaluation methods.

\section{Conclusion}

This research adopts methods such as water chemistry, multivariate statistical analysis, and geochemical simulation. The evolution process of groundwater in the Tongzi Tunnel and the formation mechanism of main ions are analyzed. The main conclusions are as follows:

(1) $\mathrm{HCO}_{3}{ }^{-}$is the dominant anion in the research area while $\mathrm{Ca}^{2+}$ is the dominant cation in the research area. The type of water chemistry is related to the lithology of the formation. The natural water body is mainly carbonate calcium water, while the content of $\mathrm{SO}_{4}{ }^{2-}, \mathrm{Na}^{+}$, and $\mathrm{K}^{+}$in the groundwater of coal strata increases, and the water chemical type tends to sulfate sodium water. It is essentially consistent with the chemical characteristics of the water intake drilled in the Tuanyuan Coal Mine during the tunnel's early stages; tunnel construction uses karst fractures and hydraulic fracturing effects to bring coal aquifers into the tunnel

(2) Water-rock interaction is the main genetic mechanism of ions. The dissolution of carbonate minerals reaches saturation, which has contributed most of the $\mathrm{HCO}_{3}{ }^{-}, \mathrm{Ca}^{2+}$, and $\mathrm{Mg}^{2+}$ in the water. The sulfate rock minerals such as alum and gypsum are not saturated in dissolution and are the main sources of $\mathrm{Ca}^{2+}, \mathrm{Mg}^{2+}$, and $\mathrm{SO}_{4}{ }^{2-}$ in the later stage. $\mathrm{F}^{-}$is mainly from fluorite. After the tunnel construction, $\mathrm{CO}_{2}$ in the air dissolves in the water, which has an important influence on the $\mathrm{pH}$ adjustment of the water

(3) Except for the dissolution of silicate rock, $\mathrm{Na}^{+}$and $\mathrm{K}^{+}$mainly come from the reverse exchange of cations. The strong reverse exchange of cations in 
coal-measure formations is also the cause of the transformation of cations from $\mathrm{Ca}^{2+}$ and $\mathrm{Mg}^{2+}$ to $\mathrm{Na}^{+}$and $\mathrm{K}^{+}$in the water samples of group IV

(4) Clustering and principal component analysis show that the 38 groups of samples can be divided into 7 clusters; the water samples are concentrated in clusters 1,3 , and 5 . The first cluster is dominated by group IV. The lithology of the aquifer is limestone intercalated with carbonaceous mudstone, carbonaceous mudstone, and coal-measure strata, which represents the weathering and dissolution of sulfate rock and ion exchange. The third cluster is dominated by surface river water, representing the action of water-rock in natural water bodies. The fifth cluster is dominated by water samples of group V, the aquifer lithology is limestone and coal-measure strata, and the reverse cation exchange behavior is weaker than that of group IV

(5) The groundwater quality is mostly Grade IV, with 28 groups, accounting for $73.6 \%$, and there are 5 groups of Class $\mathrm{V}$ water; $\mathrm{NO}_{3}{ }^{-}$and $\mathrm{F}^{-}$are the main pollution factors. Followed by $\mathrm{Fe}, \mathrm{pH}$, conventional ions in groundwater have little effect on water quality. There is no agricultural activity over the tunnel, and pollution may be caused by special ground or tunnel construction. Hydrochemical evidence indicates that aquifer has hydraulic connection

\section{Data Availability}

The data used to support the findings of this study are available from the corresponding author upon request.

\section{Conflicts of Interest}

The authors declare that they have no conflicts of interest.

\section{Acknowledgments}

This work was supported by the Major Scientific and Technological Projects of Guizhou Province (Qiankehe major special project [2018] 3011), Natural Science Foundation of Guizhou Province (qkeheji [2019] No. 1057), Regional First-Class Discipline Construction Project in Guizhou Province (QYNYL [2017] 0013), Guiyang Metro Line 3 Phase I Engineering Research Project (Project No. GD3FW-YJ-05-2020-13-ZB), and Scientific Research Project of Guiyang Rail Transit Line 2 Phase I Project (Project No. D2(I)-FW-YJ-2019-001-WT).

\section{References}

[1] Q. Zhang, B. X. Huang, M. C. He, and S. Guo, "A numerical investigation on the hydraulic fracturing effect of water inrush during tunnel excavation," Geofluids, vol. 2020, Article ID 6196327, 2020.

[2] G. T. Chae, S. T. Yun, B. Y. Choi et al., "Hydrochemistry of urban groundwater, Seoul, Korea: the impact of subway tun- nels on groundwater quality," Journal of Contaminant Hydrology, vol. 101, no. 1-4, pp. 42-52, 2008.

[3] C. Butscher, P. Huggenberger, and E. Zechner, "Impact of tunneling on regional groundwater flow and implications for swelling of clay-sulfate rocks," Engineering Geology, vol. 117, no. 3-4, pp. 198-206, 2011.

[4] A. Pina, L. D. Donado, S. Blake, and T. Cramer, "Compositional multivariate statistical analysis of the hydrogeochemical processes in a fractured massif: La Linea tunnel project, Colombia," Applied Geochemistry, vol. 95, pp. 1-18, 2018.

[5] F. Mossmark, K. K. Annertz, L. O. Ericsson, and M. Norin, "Hydrochemical impact of construction of the western section of the Hallandsås rail tunnel in Sweden," Bulletin of Engineering Geology \& the Environment, vol. 76, no. 2, pp. 751-769, 2017.

[6] M. Ćuk, I. Jemcov, A. Mladenović, and M. Ilić, "Hydrochemical impact of the hydraulic tunnel on groundwater in the complex aquifer system in Pirot, Serbia," Carbonates and Evaporites, vol. 35, no. 2, 2020.

[7] F. Mossmark, L. O. Ericsson, L. M. Norin, and L. O. Dahlström, "Hydrochemical changes caused by underground constructions - a case study of the Kattleberg rail tunnel," Engineering Geology, vol. 191, pp. 86-98, 2015.

[8] M. H. Ghobadi, M. Firuzi, and E. Asghari-Kaljahi, "Relationships between geological formations and groundwater chemistry and their effects on the concrete lining of tunnels (case study: Tabriz metro line 2)," Environmental Earth Sciences, vol. 75, no. 12, pp. 987.1-987.14, 2016.

[9] M. F. Howladar and M. M. Rahman, "Characterization of underground tunnel water hydrochemical system and uses through multivariate statistical methods: a case study from Maddhapara Granite Mine, Dinajpur, Bangladesh," Environmental Earth Sciences, vol. 75, no. 24, p. 1501, 2016.

[10] K. Megherfi, M. Maza, A. Saou, and J. L. Seidel, "Hydrochemical and statistical study of karstic spring waters of Bejaia coastal area (North Algeria)," Arabian Journal of Geosciences, vol. 13, no. 11, pp. 1-19, 2020.

[11] M. A. Engle and E. L. Rowan, "Geochemical evolution of produced waters from hydraulic fracturing of the Marcellus Shale, northern Appalachian Basin: a multivariate compositional data analysis approach," International Journal of Coal Geology, vol. 126, pp. 45-56, 2014.

[12] C. Pan, K. Ng, and A. Richter, "An integrated multivariate statistical approach for the evaluation of spatial variations in groundwater quality near an unlined landfill," Environmental Science and Pollution Research, vol. 26, no. 6, pp. 5724-5737, 2019.

[13] A. Kumar, G. Matta, and S. Bhatnagar, "A coherent approach of water quality indices and multivariate statistical models to estimate the water quality and pollution source apportionment of River Ganga System in Himalayan region, Uttarakhand, India," Environmental Science and Pollution Research, vol. 28, no. 31, pp. 42837-42852, 2020.

[14] P. Prusty and S. H. Farooq, "Application of water quality index and multivariate statistical analysis for assessing coastal water quality," Environmental Processes, vol. 7, no. 3, 2020.

[15] X. Li, P. Wu, Z. Han, X. Zha, H. Ye, and Y. Qin, "Effects of mining activities on evolution of water quality of karst waters in Midwestern Guizhou, China: evidences from hydrochemistry and isotopic composition," Environmental Science and Pollution Research, vol. 25, 2018. 
[16] H. Huang, Z. H. Chen, and T. Wang, "Characteristics and processes of hydrogeochemical evolution induced by long-term mining activities in karst aquifers, southwestern China," Environmental Science and Pollution Research, vol. 26, no. 29, pp. 30055-30068, 2019.

[17] R. Sarikhani, A. G. Dehnavi, Z. Ahmadnejad, and N. Kalantari, "Hydrochemical characteristics and groundwater quality assessment in Bushehr Province, SW Iran," Environmental Earth Sciences, vol. 74, no. 7, pp. 6265-6281, 2015.

[18] M. Abbas, S. L. Shen, H. M. Lye, A. N. Zhou, and S. Rashid, "Evaluation of the hydrochemistry of groundwater at Jhelum Basin, Punjab, Pakistan," Environmental Earth Sciences, vol. 80 , no. $8,2021$.

[19] F. Touhari, M. Meddi, M. Mehaiguene, and M. Razack, "Hydrogeochemical assessment of the Upper Cheliff groundwater (North West Algeria)," Environmental Earth Sciences, vol. 73, 2015.

[20] T. G. Alharbi and F. K. Zaidi, "Hydrochemical classification and multivariate statistical analysis of groundwater from Wadi Sahba area in central Saudi Arabia," Arabian Journal of Geosciences, vol. 11, no. 20, 2018.

[21] M. A. Ansari, A. Deodhar, and U. S. Kumar, "Modeling of geochemical processes and multivariate statistical analysis for hydrochemical assessment of spring water of the Outer Himalaya, India," Environmental Earth Sciences, vol. 78, no. 24, 2019.

[22] D. D. Wang, C. D. Yang, and L. M. Shao, "The spatiotemporal evolution of hydrochemical characteristics and groundwater quality assessment in Urumqi, Northwest China," Arabian Journal of Geosciences, vol. 14, no. 3, 2021.

[23] H. Y. Wei, X. J. Liang, S. H. Liu, M. J. Liu, and C. L. Xiao, "Hydrochemical evolution of groundwater in Dehui, China," Water, vol. 12, no. 12, p. 3378, 2020.

[24] J. Xiao, Z. D. Jin, F. Zhang, and W. Jin, "Major ion geochemistry of shallow groundwater in the Qinghai Lake catchment, NE Qinghai-Tibet Plateau," Environmental Earth Sciences, vol. 67, no. 5, pp. 1331-1344, 2012.

[25] J. Mallick, C. K. Singh, M. K. AlMesfer et al., "Hydro-geochemical assessment of groundwater quality in Aseer Region, Saudi Arabia," Water, vol. 10, no. 12, 2018.

[26] I. Hassen, F. Hamzaoui-Azaza, and R. Bouhlila, “Application of multivariate statistical analysis and hydrochemical and isotopic investigations for evaluation of groundwater quality and its suitability for drinking and agriculture purposes: case of Oum Ali-Thelepte aquifer, central Tunisia," Environmental Monitoring and Assessment, vol. 188, no. 3, pp. 135.1-135.20, 2016.

[27] Y. Rafighdoust, Y. Eckstein, R. M. Harami, M. H. M. Gharaie, and A. Mahboubi, "Using inverse modeling and hierarchical cluster analysis for hydrochemical characterization of springs and Talkhab River in Tang-Bijar oilfield, Iran," Arabian Journal of Geosciences, vol. 9, no. 3, p. 241, 2016.

[28] F. Liu, S. Wang, T. J. Yeh, P. Zhen, L. Wang, and L. Shi, "Using multivariate statistical techniques and geochemical modelling to identify factors controlling the evolution of groundwater chemistry in a typical transitional area between Taihang Mountains and North China Plain," Hydrological Processes, vol. 34, no. 8, pp. 1888-1905, 2020.

[29] M. Maghraby, "Hydrogeochemical characterization of groundwater aquifer in Al-Madinah Al-Munawarah City, Saudi Arabia," Arabian Journal of Geosciences, vol. 8, no. 6, pp. 1-16, 2015. 